\title{
Diurnal cycle and multi-decadal trend of formaldehyde in the remote atmosphere near $46^{\circ} \mathrm{N}$
}

\author{
Bruno Franco $^{1}$, Eloise A. Marais ${ }^{2}$, Benoît Bovy ${ }^{1}$, Whitney Bader ${ }^{1}$, Bernard Lejeune ${ }^{1}$, Ginette Roland ${ }^{1}$, \\ Christian Servais $^{1}$, and Emmanuel Mahieu ${ }^{1}$ \\ ${ }^{1}$ Institute of Astrophysics and Geophysics, University of Liège, Liège, Belgium \\ ${ }^{2}$ School of Engineering and Applied Sciences, Harvard University, Cambridge, MA, USA \\ Correspondence to: Bruno Franco (bruno.franco@ulg.ac.be)
}

Received: 28 September 2015 - Published in Atmos. Chem. Phys. Discuss.: 9 November 2015

Revised: 29 February 2016 - Accepted: 21 March 2016 - Published: 31 March 2016

\begin{abstract}
Only very few long-term records of formaldehyde $(\mathrm{HCHO})$ exist that are suitable for trend analysis. Furthermore, many uncertainties remain as to its diurnal cycle, representing a large short-term variability superimposed on seasonal and inter-annual variations that should be accounted for when comparing ground-based observations to, e.g., model results. In this study, we derive a multidecadal time series (January 1988-June 2015) of HCHO total columns from ground-based high-resolution Fourier transform infrared (FTIR) solar spectra recorded at the highaltitude station of Jungfraujoch (Swiss Alps, $46.5^{\circ} \mathrm{N}, 8.0^{\circ} \mathrm{E}$, 3580 ma.s.1.), allowing for the characterization of the midlatitudinal atmosphere for background conditions. First we investigate the $\mathrm{HCHO}$ diurnal variation, peaking around noontime and mainly driven by the intra-day insolation modulation and methane $\left(\mathrm{CH}_{4}\right)$ oxidation. We also characterize quantitatively the diurnal cycles by adjusting a parametric model to the observations, which links the daytime to the HCHO columns according to the monthly intra-day regimes. It is then employed to scale all the individual FTIR measurements on a given daytime in order to remove the effect of the intra-day modulation for improving the trend determination and the comparison with $\mathrm{HCHO}$ columns simulated by the state-of-the-art GEOS-Chem v9-02 chemical transport model. Such a parametric model will be useful to scale the Jungfraujoch HCHO columns on satellite overpass times in the framework of future calibration/validation efforts of space-borne sensors. GEOS-Chem sensitivity tests suggest then that the seasonal and inter-annual HCHO column variations above Jungfraujoch are predominantly led by the atmospheric $\mathrm{CH}_{4}$ oxidation, with a maximum contribu-
\end{abstract}

tion of $25 \%$ from the anthropogenic non-methane volatile organic compound precursors during wintertime. Finally, trend analysis of the so-scaled 27-year FTIR time series reveals a long-term evolution of the HCHO columns in the remote troposphere to be related to the atmospheric $\mathrm{CH}_{4}$ fluctuations and the short-term $\mathrm{OH}$ variability: $+2.9 \%$ year $^{-1}$ between 1988 and $1995,-3.7 \%$ year $^{-1}$ over 1996-2002 and $+0.8 \%$ year $^{-1}$ from 2003 onwards.

\section{Introduction}

Formaldehyde (HCHO) is the most abundant aldehyde and one of the highest reactive species in the Earth's atmosphere, with a mid-day lifetime on the order of a few hours (Logan et al., 1981; Possanzini et al., 2002). Being a product of the oxidation of most of the volatile organic compounds (VOCs), $\mathrm{HCHO}$ plays a primary role in tropospheric chemistry and in the control of air quality. Besides dry and wet deposition of generally lesser importance (Atkinson, 2000), HCHO is predominantly removed from the atmosphere via catalytic pathways that are photochemically driven (Luecken et al., 2012). Indeed, large losses occur when $\mathrm{HCHO}$ reacts with the hydroxyl radicals $(\mathrm{OH})$ available in the atmosphere to yield water vapor $\left(\mathrm{H}_{2} \mathrm{O}\right)$ and the $\mathrm{HCO}$ radical. By consuming $\mathrm{OH}$, the main sink of methane $\left(\mathrm{CH}_{4}\right)$ in the troposphere, the $\mathrm{HCHO}$ abundance contributes to increasing the lifetime of this major greenhouse gas. HCHO also decomposes by photolysis either in $\mathrm{H}_{2}$ (molecular hydrogen) and $\mathrm{CO}$ (carbon monoxide) or in $\mathrm{H}$ (hydrogen) and $\mathrm{HCO}$. Since $\mathrm{HCO}$ reacts with oxygen, all these catalytic pathways release $\mathrm{CO}$ and hydrogen oxides 
$\left(\mathrm{HO}_{x}\right)$, making $\mathrm{HCHO}$ a key component in the production of CO by oxidation of hydrocarbons (Cantrell et al., 1990; Anderson et al., 1996; Calvert et al., 2000; Fried et al., 2002). As $\mathrm{HO}_{x}$ radicals are major oxidizers in the atmosphere, $\mathrm{HCHO}$ also constitutes a useful tracer of the atmospheric oxidative capacity (Staffelbach et al., 1991). Moreover, in the presence of sufficient amounts of nitrogen oxides $\left(\mathrm{NO}_{x}\right)$, for instance in polluted air masses over urban areas (Hak et al., 2005), the $\mathrm{HO}_{x}$ produced by the $\mathrm{HCHO}$ removal processes converts nitric oxide to nitrogen dioxide, which results in a net production of tropospheric ozone by photolysis $\left(\mathrm{O}_{3}\right.$; Cantrell et al., 1990; Houweling et al., 1998; Hak et al., 2005; Kanakidou et al., 2005).

On the global scale, $\mathrm{CH}_{4}$ oxidation by $\mathrm{OH}$ constitutes the main source throughout the background troposphere, accounting for more than half of the overall production, while the remainder generally results from the oxidation of most of the non-methane VOCs (NMVOCs). However, where strong NMVOC emissions take place over continents, the oxidation of these compounds can dominate the methane-originated HCHO production, especially in the continental boundary layer (Millet et al., 2008; Pfister et al., 2008; Dufour et al., 2009a, b; Stavrakou et al., 2009a, b). Among the NMVOCs emitted over continents, biogenic compounds are dominant during the growing season of vegetation, providing $\sim 85 \%$ of the total emissions, with the largest contribution coming from isoprene (e.g., Palmer et al., 2003, 2006; Millet et al., 2008). Global HCHO production from anthropogenic NMVOCs is relatively reduced, but is significantly enhanced over largely populated and industrialized areas. NMVOCs from pyrogenic sources (mainly biomass burning) generally provide small $\mathrm{HCHO}$ contributions on the global scale, although fire events can enhance $\mathrm{HCHO}$ emissions in specific areas (see, e.g., Vigouroux et al., 2009). In addition, only a negligible fraction of $\mathrm{HCHO}(<1 \%)$ results from direct emissions to the atmosphere by various sources such as biomass burning, vegetation or incomplete fossil fuel combustion (e.g., Carlier et al., 1986; Lee et al., 1997; Hak et al., 2005; Herndon et al., 2005; Fu et al., 2007; De Smedt et al., 2010).

Formaldehyde has already been intensely observed, using measurements obtained from in situ instruments (e.g., de Serves, 1994; DiGangi et al., 2011, 2012), aircraft campaigns (e.g., Fried et al., 2002, 2008, 2011; Frost et al., 2002; Wert et al., 2003) and various satellite sensors (e.g., Chance et al., 2000; Wittrock et al., 2006; Dufour et al., 2009a, b; Stavrakou et al., 2009a, b, 2015; De Smedt et al., 2010, 2015; Marais et al., 2012, 2014), as well as ground-based remote measurements derived from UV-Visible passive MultiAXis Differential Optical Absorption Spectroscopy (MAXDOAS) instruments (e.g., Heckel et al., 2005; Pikelnaya et al., 2007; Inomata et al., 2008; Vigouroux et al., 2009; Irie et al., 2011; Wagner et al., 2011; Pinardi et al., 2013; Franco et al., 2015b) and from high-resolution infrared solar spectra recorded with Fourier transform infrared (FTIR) spectrometers (e.g., Mahieu et al., 1997; Notholt et al., 1997; Jones et al., 2009; Vigouroux et al., 2009; Paton-Walsh et al., 2010; Viatte et al., 2014; Franco et al., 2015b). However, few long-term trends of $\mathrm{HCHO}$ loadings exist that are suitable for trend analysis, particularly due to the lack of extended consistent data sets. Offering regular and quasi global geographical sampling of the Earth's atmosphere, UV-Vis satellite sensors such as SCIAMACHY (SCanning Imaging Absorption spectroMeter for Atmospheric CHartographY), GOME, GOME-2 (Global Ozone Monitoring Experiment) and OMI (Ozone Monitoring Instrument) provide some sensitivity in the free troposphere and have been used recently to produce regional decadal trends of $\mathrm{HCHO}$ columns at the global scale (De Smedt et al., 2010, 2015). Nonetheless, most spaceborne observational campaigns are time-limited, added to the fact that such measurements can be considerably affected by instrumental ageing as well as by noise and error sources in the lowermost atmospheric layers, where the bulk of $\mathrm{HCHO}$ lies.

Although the seasonal intra-day variation of $\mathrm{HCHO}$ has been studied in field campaigns in different environments (Junkermann, 2009; Choi et al., 2010; MacDonald et al., 2012) or using ground-based MAX-DOAS and space-borne UV-Vis measurements at various locations (De Smedt et al., 2015; Stavrakou et al., 2015), consistent diurnal observations of HCHO columns remain sparse and time-limited. Hence the uncertainties on the intra-day cycle remain high, added to the fact that the diurnal pattern of HCHO may vary considerably from site to site according to many local factors, such as the emissions of NMVOC precursors, the chemical regime and the influence of the planetary boundary layer. More particularly, the HCHO diurnal cycle may be responsible for significant short-term variability that needs to be accounted for when comparing results derived from space-borne instruments, according to their respective overpass times. Furthermore, the $\mathrm{HCHO}$ intra-day modulation remains incompletely captured by the chemistry transport models (CTMs), especially for remote conditions (Stavrakou et al., 2015). Therefore, the characterization of the HCHO diurnal cycle using high-quality ground-based observations is definitely required for validation/calibration efforts of satellite sensors and models.

Ground-based instruments, such as the high-resolution FTIR spectrometers distributed worldwide at strategic locations and part of the Network for the Detection of Atmospheric Climate Change (NDACC; see http://ndacc.org), are important contributors to the monitoring of the Earth's atmosphere. An optimized retrieval strategy has been recently developed to derive $\mathrm{HCHO}$ total columns from groundbased FTIR solar spectra recorded at the high-altitude NDACC station of Jungfraujoch (Swiss Alps, $46.5^{\circ} \mathrm{N}$, $8.0^{\circ} \mathrm{E}, 3580 \mathrm{~m}$ a.s.l.). The results have been successfully validated against MAX-DOAS measurements and simulation of two CTMs, GEOS-Chem (Goddard Earth Observing System - chemical transport model; Bey et al., 2001) and IMAGES 
v2 (Intermediate Model of Annual and Global Evolution of Species; Stavrakou et al., 2013), over the 2010-2012 time period (Franco et al., 2015b). The Jungfraujoch FTIR observational database now covers more than 30 years (back to 1988 in the case of HCHO observations) and is unique worldwide in terms of the quality and density of the measurements as well as of their temporal coverage. Time series of high-quality geophysical data derived from this database are particularly appropriate for multi-decadal studies of many important constituents of the Earth's atmosphere, including $\mathrm{HCHO}$ and its VOC precursors. Used as comparative and complementary data, they are also of crucial importance for the calibration and validation of models as well as of current and future satellite sensors.

In the present study, we use the observational database of ground-based solar spectra recorded by two high-resolution FTIR spectrometers operated at the Jungfraujoch station, in order to produce a 27-year time series of the HCHO total column (from 1988 to mid-2015). To the best of our knowledge, it represents the longest time series of remote $\mathrm{HCHO}$ measurements. We first investigate the intra-day variation of HCHO total columns in the remote troposphere, using a consistent subset of observations spanning more than 20 years. As this 20-year subset provides robust statistics without inducing errors and/or biases resulting from the use of different sources of measurements, we also characterize the $\mathrm{HCHO}$ diurnal cycle on a monthly basis by adjusting a fitting parametric model to the observed intra-day variations. These parameters being determined according to the observations, we employ this model to scale all individual HCHO measurements of the entire Jungfraujoch database at a given moment of the day with the aim of removing the effect of intra-day variability in the HCHO time series. Such a parametric model will be useful for carrying out comparisons between groundbased FTIR and space-borne UV-Vis HCHO columns at the overpass time specific to each satellite sensor (e.g., 09:30 LT for GOME-2B and 13:30 LT for OMI).

In the second part of this study, we employ simulations made with the state-of-the-art GEOS-Chem 3-D CTM to investigate the main sources and drivers of $\mathrm{HCHO}$ above Jungfraujoch. First we compare the ground-based FTIR observations with HCHO total columns simulated by the CTM, taking into account the vertical resolution and specific sensitivity of the FTIR retrievals. Then sensitivity runs are performed with the aim of evaluating the contribution of different precursor species or source category (from anthropogenic, biogenic and biomass burning sources) to the HCHO loadings and seasonality.

Finally, we analyze the multi-decadal FTIR time series of the Jungfraujoch station (1988-2015) in order to study the inter-annual variability and deduce trends of $\mathrm{HCHO}$ columns in the remote troposphere of the mid-latitudinal Northern Hemisphere.

This paper is organized as follows: we briefly introduce in Sect. 2 the FTIR instrumental setups and data sets, as well as the GEOS-Chem model. In Sect. 3, we investigate the $\mathrm{HCHO}$ diurnal variation and describe the fitting parametric model and how it is adjusted to the observations. We report in Sect. 4 the results of the comparison between FTIR measurements and GEOS-Chem simulations, as well as of the sensitivity runs. Section 5 is devoted to the analysis of the 1988 2015 time series of HCHO total columns above the Jungfraujoch station, involving trends determination. Section 6 concludes this study with discussions of the results and identifies avenues for future work.

\section{Data sets}

\subsection{FTIR instrumentation and measurements}

The long-term HCHO time series presented and investigated in this study has been produced from the analysis of solar spectra recorded between January 1988 and June 2015 under clear-sky conditions at the high-altitude International Scientific Station of the Jungfraujoch (hereafter ISSJ; Swiss Alps, $46.5^{\circ} \mathrm{N}, 8.0^{\circ} \mathrm{E}, 3580 \mathrm{~m}$ a.s.1.). These spectra were recorded using two very high spectral resolution FTIR spectrometers. A "home-made" instrument was primarily in operation until the mid-1990s and then progressively replaced by a more sensitive commercial Bruker-120 HR instrument. A thorough description of the instrumentation is given by Zander et al. (2008). The consistency among the HCHO columns retrieved from the two subsets is evaluated in Sect. 5.1 using all available coincident measurement days of 1995-1997.

The ISSJ is mainly located in the free troposphere during winter and represents a unique site to study the atmospheric background conditions over central Europe. During the rest of the year, injections of air masses from the planetary boundary layer can occur, bringing biogenic and anthropogenic pollutants from the nearby valleys. Furthermore, the very high dryness due to the altitude, combined with the presence of the Aletsch Glacier (adding to the local dryness) in the immediate vicinity of the station, limits significantly the interference by water vapor in the infrared solar measurements. More details regarding the measurement site can be found in Zander et al. (2008) and Franco et al. (2015b), as well as in references therein.

The overall database investigated here consists of 10979 solar spectra, of which 1436 were recorded by the "homemade" spectrometer over the 1988-1997 period and 9542 were obtained with the Bruker instrument between 1995 and June 2015 (referred to below as the LIEGE and BRUKER data sets, respectively), both equipped with indium antimonide ( $\mathrm{InSb}$ ) cooled detectors. The spectra were recorded using optical filters maximizing the signal-to-noise $(\mathrm{S} / \mathrm{N})$ ratio over the $2400-3310 \mathrm{~cm}^{-1}$ spectral domain, thus encompassing the $v_{1}$ infrared band of $\mathrm{HCHO}$ centered at $2783 \mathrm{~cm}^{-1}$. The typical spectral resolution (defined here as twice the maximum optical path difference) alternates be- 
tween 0.003 and $0.005 \mathrm{~cm}^{-1}$ for both instruments, with the highest resolution adopted for minimum variation of the airmass and observing geometry, predominantly around midday. S / N ratios vary from 550 to more than 3100 (average spectra resulting from several successive individual scans).

The retrieval strategy applied to both spectral data sets is the one developed and described by Franco et al. (2015b). A short summary of this strategy is given in Table 1. Characterization of the FTIR retrievals indicates a sensitivity throughout the troposphere (up to $12 \mathrm{~km}$ altitude). The mean degree of freedom for signal (DOFS) over the entire data set is $\sim 1$; hence, only total columns of HCHO may be obtained. In addition, the individual observations characterized by a DOFS value lower than 0.35 have been discarded. This DOFS threshold was set arbitrarily to ensure sufficient statistics at low zenith angles for representing the HCHO diurnal cycle around mid-day (see more details in Sect. 3.2). Franco et al. (2015b) also provide a complete error budget of the $\mathrm{HCHO}$ measurements, quoting the total systematic and random components at \pm 14 and $\pm 21 \%$, respectively.

\subsection{GEOS-Chem simulations and processing}

GEOS-Chem is a global 3-D chemical transport model capable of simulating global trace gas (more than 100 tracers) and aerosol distributions. In the present study, GEOSChem is driven by the Goddard Earth Observing System v5 (GEOS-5) assimilated meteorological fields from the NASA Global Modeling Assimilation Office (GMAO). The GEOS5 data are available at a native horizontal resolution of $0.5^{\circ} \times 0.667^{\circ}$ and at a $6 \mathrm{~h}$ temporal frequency $(3 \mathrm{~h}$ for surface variables and mixing depths). These meteorological fields provide a description of the atmosphere on the basis of 72 hybrid pressure $\sigma$ levels from the surface up to $0.01 \mathrm{hPa}$. For the simulations used here, the GEOS-5 meteorological fields are degraded to a $2^{\circ} \times 2.5^{\circ}$ horizontal resolution and 47 vertical levels, lumping together levels above $\sim 80 \mathrm{hPa}$. We apply the standard full chemistry GEOS-Chem simulation that includes detailed $\mathrm{O}_{3}-\mathrm{NO}_{x}-\mathrm{VOC}$-aerosol coupled chemistry described by Bey et al. (2001) and Park et al. (2004), with updates by Mao et al. (2010).

Conversely to Franco et al. (2015b), who used GEOSChem version 9-01-03, we employ here model version 9-02 (http://acmg.seas.harvard.edu/geos/doc/archive/ man.v9-02/index.html) that implements a new isoprene oxidation scheme as standard. This chemistry is largely based on the work of Paulot et al. (2009a, b) and has been proven to yield more $\mathrm{HCHO}$ from the isoprene oxidation pathways for weakly polluted conditions (under very low $\mathrm{NO}_{x}$ concentrations; see Marais et al., 2012). Nonetheless, results provided by version 9-01-03 of GEOS-Chem (according to the same standard full chemistry simulation) are also provided hereafter for comparison purposes. The isoprene oxidation scheme applied in GEOS-Chem v9-01-03 is described in Mao et al. (2013).
In GEOS-Chem, the global biomass burning emissions are derived from the Global Fire Emissions Database (GFED) v3 (van der Werf et al., 2010) and the global biogenic emissions are obtained with the Model of Emissions of Gases and Aerosols from Nature (MEGAN) v2.0 (Guenther et al., 2006) in GEOS-Chem v9-01-03 and v2.1 (Guenther et al., 2012) in version 9-02. Over Europe, the anthropogenic emissions of $\mathrm{CO}, \mathrm{NO}_{x}, \mathrm{SO}_{x}$ (sulfur oxides), ammonia and NMVOCs are provided by the European Monitoring and Evaluation Programme (EMEP; http://www.ceip.at/) regional inventory for the year 2010 (Simpson et al., 2010), except for ethane and propane, which are derived from an offline simulation (Xiao et al., 2008), and acetone, which is from the REanalysis of the TROpospheric chemical composition (RETRO; http://gcmd.gsfc.nasa.gov/records/GCMD_ GEIA_RETRO.html) global emission inventory (Van het Bolscher et al., 2008) for the base year 2000. The global and regional inventories are scaled to the years of interest using energy statistics (van Donkelaar et al., 2008). Annual average $\mathrm{CH}_{4}$ concentrations are prescribed over four latitude bands $\left(0-30 ; 30-90^{\circ}\right)$ on the basis of $\mathrm{CH}_{4}$ measurements from the NOAA Global Monitoring Division flask measurements.

In addition to the standard full chemistry simulations of GEOS-Chem v9-02 (hereafter called standard runs), three other runs also implementing the standard full chemistry have been performed with version 9-02, but in each of them either the anthropogenic, biogenic or biomass burning emissions of NMVOCs and NO (nitric oxide) have been turned off. These additional simulations are referred to below as non-anthropogenic, non-biogenic and non-biomass burning runs, respectively. It is worth noting that $\mathrm{CH}_{4}$ concentrations in these sensitivity runs are still derived from the NOAA measurements, as for the standard simulation. The different GEOS-Chem data sets used in the present study are obtained from July 2005 to May 2013 simulations, for which the GEOS-5 meteorological fields are available. These simulations were preceded by a 1 -year run for chemical initialization, restarted several times to remove the effect of initial conditions.

The GEOS-Chem outputs consist of HCHO volume mixing ratio (VMR) profiles simulated at the closest pixel to the Jungfraujoch station and saved at a $3 \mathrm{~h}$ time step. The comparisons between the GEOS-Chem simulations and the FTIR total columns account for the vertical resolution and sensitivity of the FTIR retrievals. To this end, the individual VMR profiles simulated by GEOS-Chem have been regridded onto the 39-layer vertical scheme adopted at the ISSJ for the FTIR retrievals, according to a mass conservative interpolation. Then these profiles have been smoothed according to the formalism of Rodgers and Connor (2003) by convolving them with the FTIR averaging kernels, seasonally averaged over March-May, June-August, September-November and December-February, as well as over successive years, on the basis of the July 2005-May 2013 FTIR data set. The GEOS-Chem total columns have eventually been computed 
Table 1. Summary of the retrieval strategy for HCHO applied in this study above Jungfraujoch. A thorough description is given by Franco et al. (2015b).

\begin{tabular}{ll}
\hline Retrieval code & SFIT-2 v3.91 algorithm (Rinsland et al., 1998) \\
A priori profile & From WACCM v6 simulations \\
Regularization & Optimal estimation method (Rodgers, 2000) \\
Covariance profile & From WACCM v6 simulations (multiplied by 1.5) \\
Spectroscopic database & HITRAN 2008 (Rothman et al., 2009) \\
Microwindows (and interfering species) & $2763.425-2763.600 \mathrm{~cm}^{-1}\left(\mathrm{HDO}, \mathrm{CH}_{4}, \mathrm{O}_{3}, \mathrm{~N}_{2} \mathrm{O}, \mathrm{CO}_{2}\right)$ \\
& $2765.725-2765.975 \mathrm{~cm}^{-1}\left(\mathrm{HDO}, \mathrm{CH}_{4}, \mathrm{O}_{3}, \mathrm{~N}_{2} \mathrm{O}, \mathrm{CO}_{2}\right)$ \\
& $2778.200-2778.590 \mathrm{~cm}^{-1}\left(\mathrm{HDO}, \mathrm{CH}_{4}, \mathrm{O}_{3}, \mathrm{~N}_{2} \mathrm{O}, \mathrm{CO}_{2}\right)$ \\
& $2855.650-2856.400 \mathrm{~cm}^{-1}\left(\mathrm{HDO}, \mathrm{CH}_{4}, \mathrm{O}_{3}, \mathrm{~N}_{2} \mathrm{O}, \mathrm{H}_{2} \mathrm{O}\right)$ \\
\hline
\end{tabular}

from these smoothed VMR profiles by using the corresponding regridded air density profiles simulated by the model. The comparisons between the FTIR measurements and the GEOS-Chem simulations are performed over the 919 days with observations available in the July 2005-May 2013 time range.

\section{Formaldehyde diurnal variation}

\subsection{Observed intra-day modulation}

In this section, we investigate the $\mathrm{HCHO}$ diurnal variation above the ISSJ using the total column measurements derived from the January 1995-June 2015 BRUKER data set, owing to their overall improved temporal regularity and measurement density compared to the LIEGE data set. The total columns have been normalized to the mean annual pressure at the ISSJ $(654 \mathrm{hPa})$ in order to avoid the effects due to pressure variation between different days/seasons in the retrieved HCHO columns. Figure 1 shows the intra-day modulation of the $\mathrm{HCHO}$ abundance above Jungfraujoch averaged over each month of the mean year (with the HCHO total columns averaged every $0.5 \mathrm{~h}$ as grey circles), according to the FTIR observations made over the entire 1995-mid-2015 time period (a global view of the observed and modeled monthly intra-day cycles is available in Fig. 3a, Sect. 4.1).

At the global scale, the diurnal cycles of HCHO loadings depend on local chemical regimes, which generally vary across the seasons and determine the $\mathrm{HCHO}$ formation and loss, as well as local emissions of NMVOC precursors and their diurnal variability. For instance, it has been shown that daytime photochemical production and anthropogenic NMVOC emissions drive the HCHO diurnal modulation over highly populated and industrialized areas, such as in Belgium and Holland (see Stavrakou et al., 2015). However, at a remote site such as the ISSJ, located in the free troposphere during most of the year, the overall sunrise to sunset modulation of the $\mathrm{HCHO}$ total columns is predominantly driven by the atmospheric photochemistry and the $\mathrm{CH}_{4}$ oxidation (see Sect. 4.2): enhanced insolation and higher temperatures intensify the concentration in $\mathrm{OH}$ radicals and hence the pho- tochemical oxidation rate of VOC precursors of HCHO. It is characterized by a.m. increases and p.m. decreases of the HCHO columns, peaking around mid-day and in the early afternoon. The amplitude of the intra-day modulation varies largely from month to month: from $0.2 \times 10^{15}$ molec cm ${ }^{-2}$ in December up to $1.0 \times 10^{15}$ molec $\mathrm{cm}^{-2}$ during summertime. The weaker amplitude in winter is due to the relatively high solar zenith angle (SZA) around noontime, inducing less radiation, as well as to the weak moisture, both hindering the formation of $\mathrm{OH}$. A similar pattern of the $\mathrm{HCHO}$ diurnal cycle was reported over the remote ocean by MAX-DOAS measurements (Peters et al., 2012).

The FTIR measurements are irregularly distributed throughout the day, with most of the observations performed before mid-day because of frequent high cirrus cloud occurrences in the afternoon as well as the mountainous summits around the station, occulting the sun at SZA larger than $\sim 80^{\circ}$ during wintertime (see Fig. 4 in Zander et al., 2010). As a consequence, the relative uncertainty associated with the p.m. observations increases (see the error bars in Fig. 1). Furthermore, the retrievals from low-SZA spectra (around mid-day) are characterized by relatively low DOFS values, such as illustrated in Fig. 2a, due to the very weak solar absorptions by HCHO for low air masses. This contributes to increasing the uncertainty in the retrieved total columns and explains the fluctuations of the running average observed around noontime during the summer months (see Fig. 1). The diurnal variation of the $\mathrm{HCHO}$ abundance also shows for some months (e.g., August and September in Fig. 1) a small re-increase in the total columns at the end of the day. This results from the fact that only observations made during later (earlier) days of the month are available at this moment for the first (last) 6 months of the year (see Fig. 2b), due to the increasing (shortening) day length. Given the typical seasonal cycle of HCHO throughout the year, such measurements hence provide somewhat larger (lower) HCHO columns.

\subsection{Parametric model of the diurnal variation}

The diurnal modulation of the HCHO abundance above Jungfraujoch corresponds to a large short-term variability 


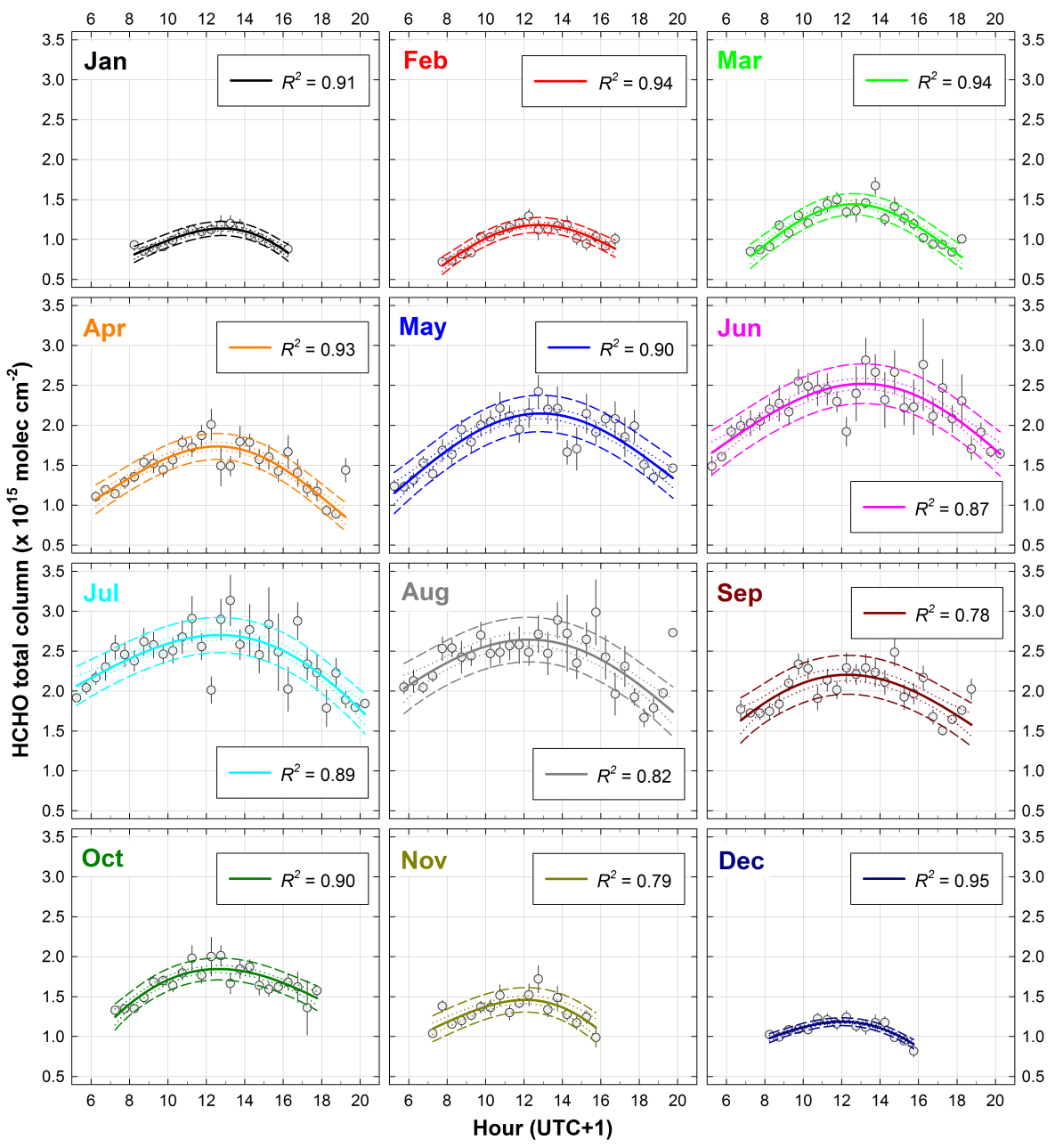

Figure 1. Intra-day variation of the $\mathrm{HCHO}$ abundance, represented by the $0.5 \mathrm{~h}$ time step average (as grey circles) and corresponding standard error of the mean (as error bars) of the HCHO total columns (in molec $\mathrm{cm}^{-2}$ ) derived from all individual observations made by the Bruker instrument between January 1995 and June 2015 at the ISSJ. It is expressed according to the hour of the day (UTC +1$)$ and for each month of the year. No smoothing has been applied here. The solid color curves are the fits of the monthly running averages of the individual observations by the parametric model (Eq. 1), associated with the $95 \%$ confidence and prediction intervals delimited by the dotted and dashed color curves, respectively. The running average used here corresponds to a $0.5 \mathrm{~h}$ time step and a $1.5 \mathrm{~h}$ wide integration length. The coefficient of determination $\left(R^{2}\right)$ of the model fit is provided for each month in the legend. All the monthly fits by the parametric model are displayed on the same graph in Fig. 3a, Sect. 4.1.

that should be accounted for when comparing ground-based observations to, e.g., satellite measurements and model results. Moreover, it is worth describing such a modulation in order to remove it before investigating seasonal/inter-annual variability of $\mathrm{HCHO}$ in the following parts of this study. Therefore, we have adjusted a fitting parametric model to each monthly subset, the results being presented in Fig. 1. To this end, the intra-day modulation used to adjust the parametric model consists of a running average (not shown in Fig. 1) of all individual FTIR measurements within each month, calculated using a $0.5 \mathrm{~h}$ time step and a $1.5 \mathrm{~h}$ wide integration length (compatible with the HCHO lifetime). The smoothing associated with the running average helps to dampen the contribution of very high $\mathrm{HCHO}$ loadings that correspond to "polluting" events. The previous analysis has highlighted the fact that modeling the HCHO diurnal cycle merely according to the seasons would not capture the large differences observed from month to month, especially during spring and fall. Hence we have also adjusted the fitting parametric model while considering monthly diurnal cycles, in order to keep enough p.m. observations (i.e., statistics) for adjusting the model with high reliability.

The model used here (described in Eq. 1) consists in a reparametrization of the standard statistical form of the Weibull continuous probability distribution (Weibull, 1951) of a random variable $x$. In this study, it determines the HCHO total column $(y)$ as a density function of the hour of the day $(x)$, according to the amplitude $(a)$, the scale parameter $(b)$, the 

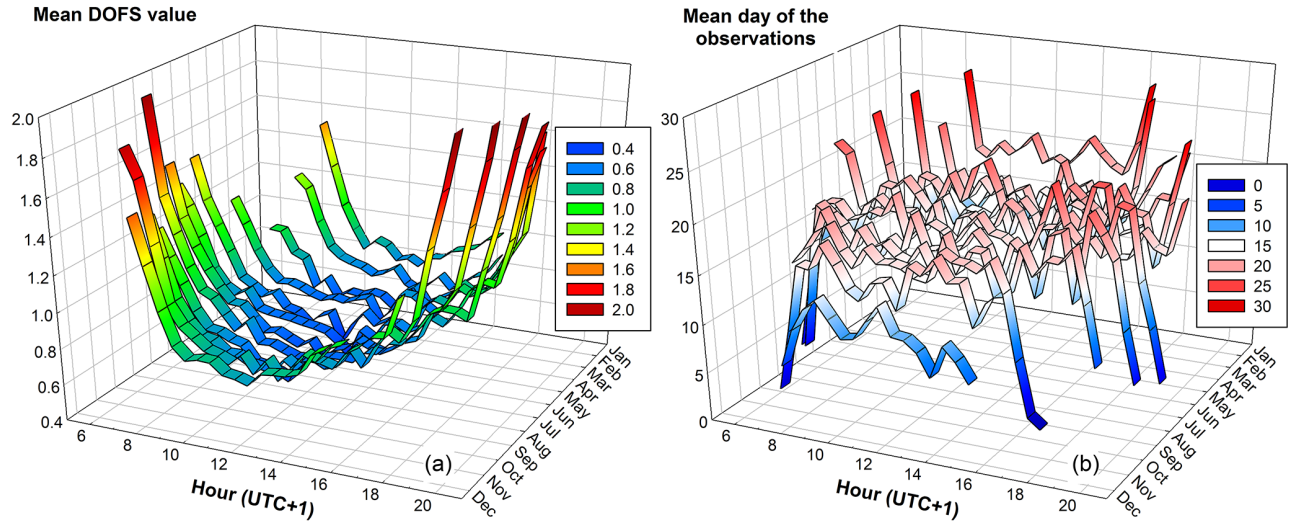

Figure 2. Average of the mean DOFS values and the mean observational day of the month (a and $\mathbf{b}$, respectively) of all individual observations made by the Bruker instrument between January 1995 and June 2015 at the ISSJ, according to the hour of the day and for each month of the year. The average has been calculated with a time step and an integration length of $0.5 \mathrm{~h}$ (no smoothing has been applied here).

shape parameter $(c)$ and the location parameter (or threshold; $x_{0}$ ) of the distribution. The Weibull density function is a versatile distribution capable of adopting the characteristics of other types of distributions, according to the value of the shape parameter $(c)$, and is widely used to mimic peaking distributions with asymmetric slopes.

$$
\begin{aligned}
y= & a\left(\frac{c-1}{c}\right)^{\left(\frac{1-c}{c}\right)} \times\left|\frac{x-x_{0}}{b}+\left(\frac{c-1}{c}\right)^{\left(\frac{1}{c}\right)}\right|^{(c-1)} \\
& \times \exp -\left|\frac{x-x_{0}}{b}+\left(\frac{c-1}{c}\right)^{\left(\frac{1}{c}\right)}\right|^{c}+\frac{c-1}{c}
\end{aligned}
$$

The model has been adjusted to the observations and the parameters calculated by using the iterative LevenbergMarquardt algorithm (Marquardt, 1963) that minimizes the sum of the squared differences between the observations and the predicted values of the model until convergence occurs (i.e., when the residuals no longer decrease significantly). The model fit for each month is represented as solid color curves in Fig. 1, along with the associated $95 \%$ confidence and prediction bands. The coefficients of determination $\left(R^{2}\right)$ calculated between the monthly observations and model fits are high and range from 0.78 to 0.95 (see Fig. 1). The parameters $a, b, c$ and $x_{0}$ determined by the adjustments are given for each month in Table S1 in the Supplement so that one may reproduce the model fits using Eq. (1).

The model is able to reproduce with reliability the diurnal modulation of HCHO loadings above Jungfraujoch and allows for its quantitative characterization for a typical day of each month of the year, thanks to the large BRUKER statistical database. Since this model is parameterized, we use it in this study to scale individual FTIR measurements on a given moment of the day before carrying out a comparison with GEOS-Chem outputs (see Sect. 4.1) and a long-term trend study (see Sect. 5.2). Nonetheless, such a model cannot be used to extrapolate the $\mathrm{HCHO}$ total columns outside the actual range of measurements. In addition, this model is only valid if the condition in Eq. (2) is true; otherwise, the Weibull distribution collapses and the results are null (e.g., for the very first hours of the day).

$x>x_{0}-b\left(\frac{c-1}{c}\right)^{\left(\frac{1}{c}\right)}$

Given the lower DOFS values characterizing the retrievals performed around mid-day, especially in summer (see Fig. 2a), the a priori profile adopted for the retrievals will have an impact on the HCHO total columns obtained from such observations. The a priori profile used in Franco et al. (2015b) for the HCHO retrieval is derived from WACCM v6 (Whole Atmosphere Community Climate Model; see, e.g., Chang et al., 2008) simulations above ISSJ over the 1980 2020 period. According to sensitivity tests adopting either a lower or higher realistic a priori profile (i.e., derived from ACE-FTS occultation measurements and GEOS-Chem simulations; see Fig. S1 in the Supplement), the diurnal cycle fitted by the parametric model will show somewhat lower or larger amplitude, respectively (see Fig. S2). We gauge at $\pm 10 \%$ the maximum systematic uncertainty that can affect the fit of the HCHO intra-day variations due to the choice of the a priori profile. Such maximum uncertainty is reached around noontime for the summer months only, and as such can be considered highly conservative.

In order to remove the effect of the intra-day cycle, the pressure-normalized total columns obtained from all individual measurements have been scaled to 09:00 $(\mathrm{UTC}+1)$ on the basis of the parametric model described previously. Using Eq. (1) that links the daytime to the HCHO columns, as well as the constant parameters determined for each month, the total column derived from a solar spectrum is scaled according to the difference between the actual time of the corresponding observation and 09:00 (UTC + 1). An example is illustrated for June by the color circles in Fig. 3a (see Sect. 4.1): 


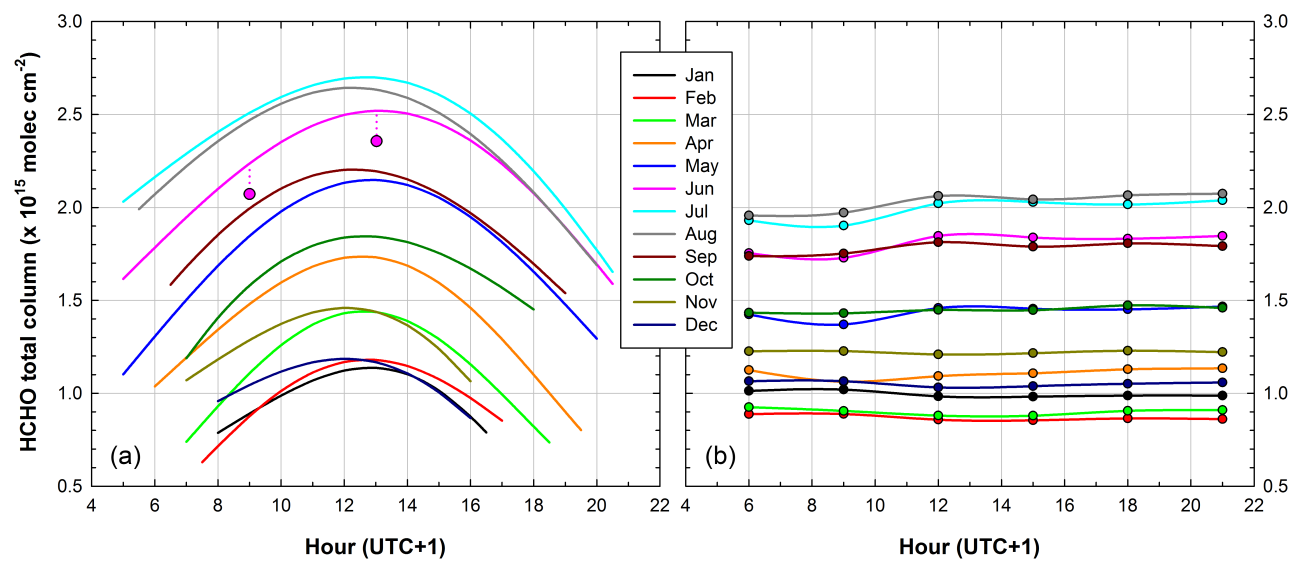

Figure 3. Monthly diurnal cycles of HCHO total columns above Jungfraujoch adjusted by the parametric model (Eq. 1) to the 1995-2015 BRUKER FTIR observations (a) and simulated by the standard run of GEOS-Chem over the July 2005-May 2013 time period (b). The red circles in frame (a) illustrate an example of the HCHO column derived from an individual observation made in June at 13:02 (UTC +1 ) and scaled to 09:00 using the parametric model of HCHO intra-day variation (see explanation in Sect. 3.2).

an initial total column of $2.356 \times 10^{15}$ molec $^{-2}$ derived from an observation made at 13:02 (UTC +1 ) is decreased to $2.072 \times 10^{15} \mathrm{molec} \mathrm{cm}^{-2}$ when scaled at 09:00. Here we have chosen 09:00 as a reference time because observations for every month are available at this moment of the day, added to the fact that the gap between the different monthly intra-day regimes in terms of $\mathrm{HCHO}$ columns is minimal in the morning.

\section{Formaldehyde simulated by GEOS-Chem}

\subsection{Comparison with the GEOS-Chem standard run}

Figure 3 presents the monthly diurnal variations as adjusted by the parametric model on the basis of the FTIR observations in Sect. 3.2 (Fig. 3a) and as derived from the $3 \mathrm{~h}$ outputs of the GEOS-Chem v9-02 standard run spanning the mid-2005-mid-2013 time period (Fig. 3b). The diurnal modulation of HCHO loadings above Jungfraujoch represents a large short-term variability superimposed on seasonal and inter-annual variations (Fig. 3a) that should be accounted for when comparing ground-based observations to, e.g., model results. However, Fig. 3b shows that GEOSChem does not capture the observed monthly intra-day variation. That a CTM is unable to simulate the observed HCHO diurnal modulation, especially for remote conditions, has already been reported with IMAGES v2 (Stavrakou et al., 2015). This can be partially explained by the fact that different oxidation pathways of VOC precursors leading the $\mathrm{HCHO}$ production, which are numerous, might not be optimally implemented (especially very short-lived VOCs) or merely not considered in the model. In addition, large uncertainties remain concerning the various sources of precursor emissions, their geographical distribution and how this latter one can influence the air masses over remote sites such as the ISSJ. Finally, the CTMs dilute local enhancements in HCHO due to their relatively coarse spatial resolution $\left(2^{\circ} \times 2.5^{\circ}\right.$ here), which also affects the comparison with observations.

For this reason, we compare in this section HCHO total columns simulated by GEOS-Chem and obtained from the 09:00 model outputs to the daily averaged FTIR total columns calculated on the basis of the 09:00-scaled individual observations (see Sect. 3.2). This comparison is made over the May 2005-June 2015 time period for the days with available FTIR observations only. In this study, some outliers, likely due to transport of air masses with high NMVOC precursor concentrations up to ISSJ, have been discarded from the FTIR data set. Indeed, the CTMs are generally unable to simulate such "polluting" events for the reasons evoked above. These outliers have been identified as the daily averaged HCHO total columns with relative anomalies to the curve fitted by the method of Gardiner et al. (2008, Sect. 5.2 and Fig. 7 here below) higher than the 95th percentile value of all relative anomalies of the 2003-2015 data set.

Figure 4 presents the good agreement $(R=0.72)$ in terms of seasonal cycles of HCHO loadings above Jungfraujoch, obtained from the FTIR observations and such as simulated by the GEOS-Chem v9-02 standard run. A similar seasonal comparison over the mid-2010-2012 time range has been carried out by Franco et al. (2015b), but involving results from the GEOS-Chem v9-01-03 standard run (in dashed red line in Fig. 4). This comparison illustrates the higher HCHO columns simulated by version 9-02 of GEOS-Chem compared to version 9-01-03, due to the implementation of the new isoprene oxidation scheme (Paulot et al., 2009a, b) that enhances the $\mathrm{HCHO}$ formation under very low $\mathrm{NO}_{x}$ concentrations. We refer to Franco et al. (2015b), Sect. 4.1, for the discussion regarding the mean seasonal bias of the GEOSChem results to the FTIR HCHO total columns, which is 


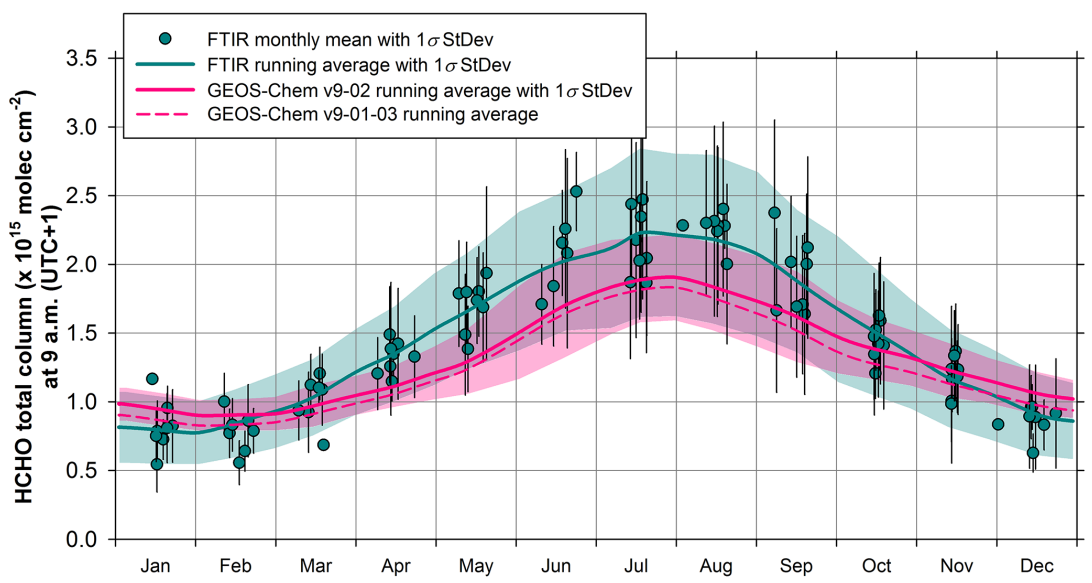

Figure 4. Monthly averaged total columns of HCHO and associated $1 \sigma$ bars displayed on a 1-year time base, from the individual 09:00 $($ UTC + 1) scaled FTIR measurements performed above the ISSJ between July 2005 and May 2013. Note that the daily observation values with relative anomalies to the curve fit calculated by Gardiner et al. (2008, Sect. 5.2), higher than the 95th percentile value of all relative anomalies of the data set, have been excluded from the present data set. The green curve and shaded area show on a 1-year time base the running mean fit to the daily averaged columns (with a 2-month wide integration time and a 15-day time step) and the associated $1 \sigma$ standard deviation, respectively. The solid red line and shaded area represent corresponding information, but deduced from the smoothed outputs of the GEOS-Chem v9-02 standard run. The dashed red line corresponds to the same 1-year time base running mean, but obtained from the smoothed outputs of the GEOS-Chem v9-01-03 standard run. Note that the $1 \sigma$ standard deviations around the running mean are calculated on the basis of the daily averaged columns and hence include inter-annual fluctuations as well as variability of the monthly mean.

here $-4.7 \pm 31.3 \%$. As the model does not reproduce the HCHO intra-day variations at the ISSJ, this bias increases to $-21.3 \pm 26.4 \%$ for the comparison involving the $12: 00$ $(\mathrm{UTC}+1)$ GEOS-Chem outputs and the 12:00-scaled individual FTIR observations (with $R=0.69$ ).

\subsection{GEOS-Chem sensitivity tests}

In this part of the study, we investigate the influence of the different categories of emission sources implemented in GEOS-Chem v9-02 on the HCHO abundance simulated by the model above Jungfraujoch. To this end, we compare the results from the standard run and from the three sensitivity runs performed without either anthropogenic, biomass burning or biogenic emissions of NMVOCs and NO. Figure 5a shows the monthly averaged HCHO total columns at the ISSJ, derived from these simulations from July 2005 to May 2013. Figure $5 \mathrm{~b}$ presents the HCHO total columns from the three sensitivity runs relative to the amount from the standard run.

In Fig. 5a and b, it can be seen that none of the missing emission sources significantly impacts the simulated HCHO loadings in summer at the ISSJ, with the HCHO columns derived from either the non-anthropogenic or non-biogenic runs still accounting for $\sim 95 \%$ of the total columns from the standard run (Fig. 5b). During this season, biogenic primary NMVOCs such as isoprene may constitute a significant source of $\mathrm{HCHO}$, especially in the continental boundary layer. However, it is most likely that a large part of these very short-lived NMVOCs are already oxidized before be- ing transported to the ISSJ. Hence these compounds do not contribute directly to the HCHO loadings above Jungfraujoch, although they release biogenic secondary products that can be transported to the upper troposphere and in turn can be oxidized, adding to the $\mathrm{HCHO}$ abundance in the upper tropospheric layers. During wintertime, the absence of anthropogenic emissions decreases the HCHO burden down to $75 \%$ of the standard run (Fig. 5b), with a DecemberFebruary average of $82 \%$ over July 2005-May 2013. Due to their longer lifetimes and more intensive anthropogenic combustion during this season, more elevated concentrations in reactive anthropogenic compounds can be measured in winter at the ISSJ (Balzani Lööv et al., 2008; Legreid et al., 2008; Starokozhev et al., 2009), which contributes to the HCHO formation. Finally, the missing biomass burning emissions have almost no effect on the simulated HCHO loadings above Jungfraujoch (Fig. 5b). These tests suggest that the contribution of anthropogenic, biogenic and pyrogenic NMVOCs to the HCHO burden above Jungfraujoch is quite limited, and that the oxidation of $\mathrm{CH}_{4}$ (not included in the emission sources shut off here) by $\mathrm{OH}$ dominates the $\mathrm{HCHO}$ production and constitutes the main driver of its seasonality.

It is worth noting that turning off the emission sources in the GEOS-Chem sensitivity tests investigated here may eventually result in slightly enhanced $\mathrm{HCHO}$ amounts (by $2-3 \%$ ) produced by GEOS-Chem compared to the standard run, as shown in Fig. $5 \mathrm{~b}$ for the non-biomass burning run and, to a lesser extent, for the non-biogenic run during winter. In these particular cases, with part of the emission sources missing globally, enhanced HCHO might be due to a lower con- 


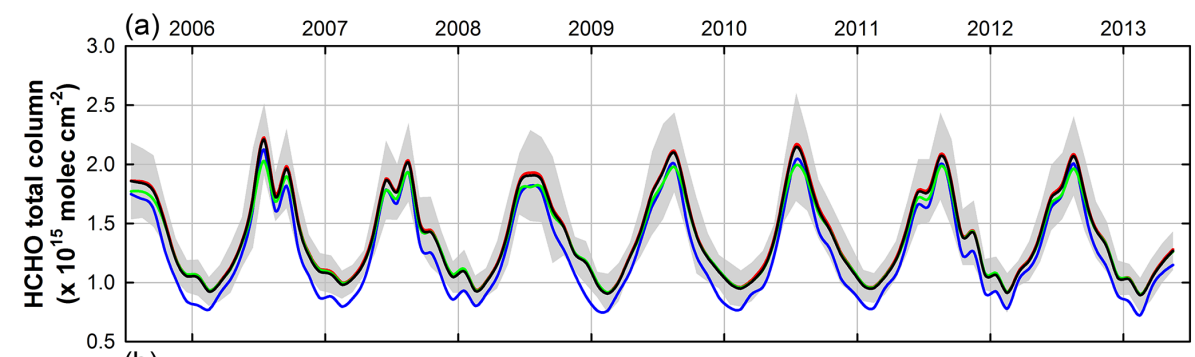

(b)
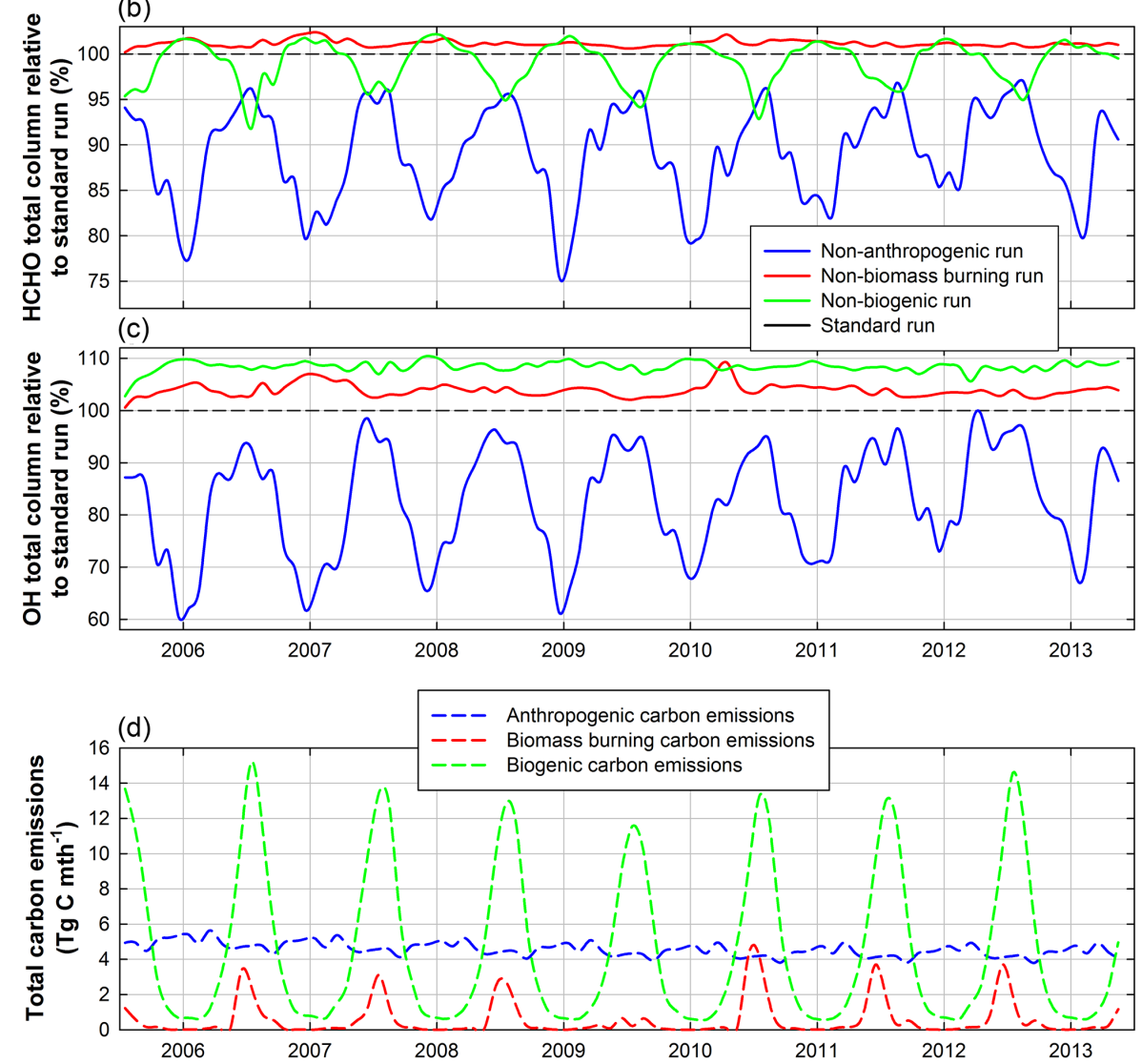

Figure 5. (a) Monthly mean of the daily averaged HCHO total column (in molec $\mathrm{cm}^{-2}$ ) above Jungfraujoch simulated by GEOS-Chem v9-02 over the July 2005-May 2013 time period, according to the standard and sensitivity (i.e., non-anthropogenic, non-biomass burning and non-biogenic) runs. In the sensitivity simulations, the anthropogenic, biomass burning and biogenic emissions of NMVOCs and NO have been shut off, while the $\mathrm{CH}_{4}$ concentrations are still derived from NOAA measurements, as for the standard simulation. The grey shaded area corresponds to the $1 \sigma$ standard deviation associated with the standard run. (b) HCHO total column from the sensitivity runs, as relative to the $\mathrm{HCHO}$ amount simulated by the standard run (in \% of the latter). (c) The same as (b) but for OH. (d) Monthly total carbon emissions (in $\mathrm{TgC} \mathrm{month}^{-1}$ ) by category, integrated over $30-60^{\circ} \mathrm{N}$ and $-130-35^{\circ} \mathrm{E}$.

centration in associated NMVOCs for which $\mathrm{OH}$ is the main sink, inducing enhanced $\mathrm{OH}$ loadings above Jungfraujoch available for oxidation of other VOC precursors of HCHO such as $\mathrm{CH}_{4}$. Indeed, Fig. 5c illustrating the monthly averaged $\mathrm{OH}$ amounts simulated by the different sensitivity runs, relative to the standard run, shows $\mathrm{OH}$ total columns from the non-biomass burning and non-biogenic runs increased by up to $10 \%$. However, it is hard to evaluate the impact of the excluded NO emissions, since this compound plays a key role in both HCHO formation (through the NMVOC oxidation pathways) and destruction (by contributing to the regeneration of $\mathrm{OH}$ ). Investigating the balance between all these reactions would require a specific study that is beyond the scope of the present work.

According to the GEOS-Chem simulation performed without anthropogenic emissions, the wintertime contribution of anthropogenic NMVOC precursors to the $\mathrm{HCHO}$ total column above Jungfraujoch varies from year to year (from 15 to $25 \%$; Fig. 5b). However, the wintertime total carbon emissions of anthropogenic origin as implemented in 
GEOS-Chem from the inventories are approximately constant throughout the entire July 2005-May 2013 time range ( $\sim 5$ Tg C month $^{-1}$; Fig. $5 \mathrm{~d}$ ) when integrated over the source regions of emissions impacting the ISSJ. According to Dils et al. (2011), this domain encompasses central and western Europe, as well as North American mid-latitudes (i.e., between $30-60^{\circ} \mathrm{N}$ and $-130-35^{\circ} \mathrm{E}$ ). Hence, this suggests that the $\mathrm{HCHO}$ production from oxidized anthropogenic compounds and its inter-annual variability at the ISSJ are mainly driven in GEOS-Chem by the simulated $\mathrm{OH}$ burden and its year-to-year fluctuation (Fig. 5c).

\section{Formaldehyde time series}

We investigate hereafter the long-term evolution of the HCHO abundance at ISSJ, using both the LIEGE and BRUKER FTIR data sets. We employ the HCHO total columns derived from all individual FTIR observations made over the 1988-2015 time period, corrected to the equivalent 09:00 values via the parametric model described previously and eventually combined as daily means.

\subsection{Consistency between the FTIR data sets}

We first evaluate the consistency of the measurements derived from both instruments. To this end, we compare the HCHO total columns derived from solar spectra recorded on the same days, using the 1995-1997 overlap time period while accounting for the diurnal modulation of the $\mathrm{HCHO}$ abundance. Figure 6 shows a scatterplot of the scaled (to 09:00) BRUKER vs. LIEGE total column daily means, including the 25 days available over the 1995-1997 years. The comparison demonstrates a very good agreement between both data sets, with a high coefficient of determination $\left(R^{2}=\right.$ 0.89 ) for both low and high HCHO columns (corresponding globally to measurements performed during winter and summer). Moreover, the mean difference between the BRUKER and LIEGE daily means is $-0.10 \pm 0.36 \times 10^{15}$ molec $\mathrm{cm}^{-2}$. Given the good consistency and absence of significant bias, the LIEGE and BRUKER data sets will be jointly used hereafter to investigate the long-term variation of the $\mathrm{HCHO}$ abundance above Jungfraujoch.

\subsection{Formaldehyde multi-decadal trend}

Combined together, the LIEGE and BRUKER data sets constitute a unique database covering more than 27 years (from January 1988 to June 2015), providing to the best of our knowledge the longest consistent time series of remote ground-based observations of $\mathrm{HCHO}$ worldwide. In this part of the study, we employ the HCHO total columns derived from all individual FTIR observations made over the 19882015 time period. The entire daily mean total column time series is illustrated in Fig. 7. We have applied to the whole data set a running mean characterized by a 3-year integration

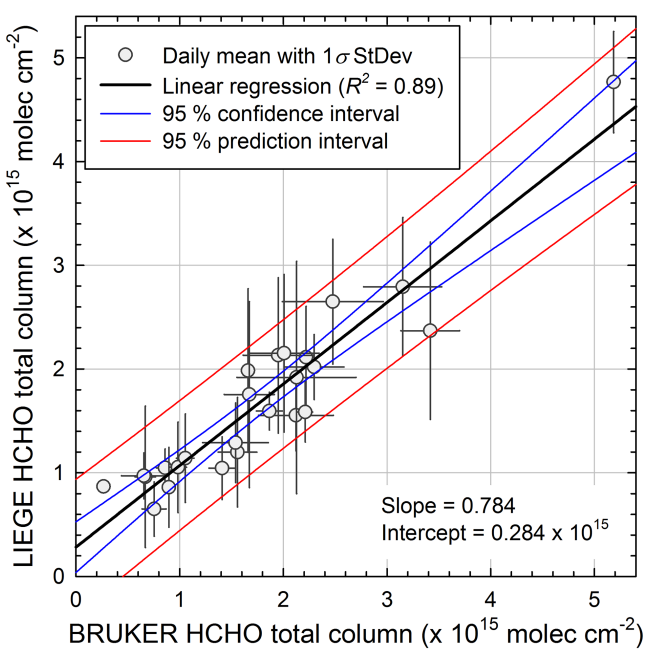

Figure 6. Scatterplot of the daily average (and the associated $1 \sigma$ standard deviation as error bars) HCHO column measurements derived from FTIR observations made by the LIEGE and BRUKER instruments at the ISSJ, over the 1995-1997 time period. These daily means are compared for days with coincident observations, after scaling to 09:00 (see text). The solid black line is the linear regression between both data sets $\left(R^{2}=0.89\right)$, along with the $95 \%$ confidence and prediction intervals delimited by the blue and red lines, respectively.

length and a 6-month time step, in order to minimize the influence of the large intra-annual variability of $\mathrm{HCHO}$. This has revealed a significant maximum of HCHO columns between the end of 1995 and early 1996, as well as a minimum around the beginning of 2003. The trend and associated uncertainty affecting each subset (i.e., the daily mean total column subsets spanning the 1988-1995, 1996-2002 and 20032015 periods, respectively) have been determined using a statistical bootstrap resampling tool (Gardiner et al., 2008) combining a linear function and a third-order Fourier series that accounts for the strong seasonal modulation of $\mathrm{HCHO}$ (in blue curve in Fig. 7).

Analysis of the whole time series indicates a statistically significant rate of change (at the $2 \sigma$ confidence level) of the $\mathrm{HCHO}$ abundance over each time period: $4.35 \pm 2.98$, $-7.22 \pm 1.97$ and $1.20 \pm 0.92 \times 10^{13}$ molec $^{-2}$ year $^{-1}$ for 1988-1995, 1996-2002 and 2003-2015, respectively. Using the 1988.0, 1996.0 and 2003.0 columns modeled by the bootstrap tool as references, we obtain the following relative annual trends: $2.94 \pm 2.02 \%$ year $^{-1}$ up to $1995,-3.68 \pm 1.00 \%$ year $^{-1}$ between 1996 and 2002, and $0.81 \pm 0.62 \%$ year $^{-1}$ from 2003 onwards. It is worth noting that the choice of the reference hour for scaling the individual $\mathrm{HCHO}$ columns has no significant impact on the calculated rates of change. For example, the relative annual trends obtained from $\mathrm{HCHO}$ total columns scaled at 12:00, i.e., when the difference between the 12 monthly intra-day regimes is near its maximum, are 


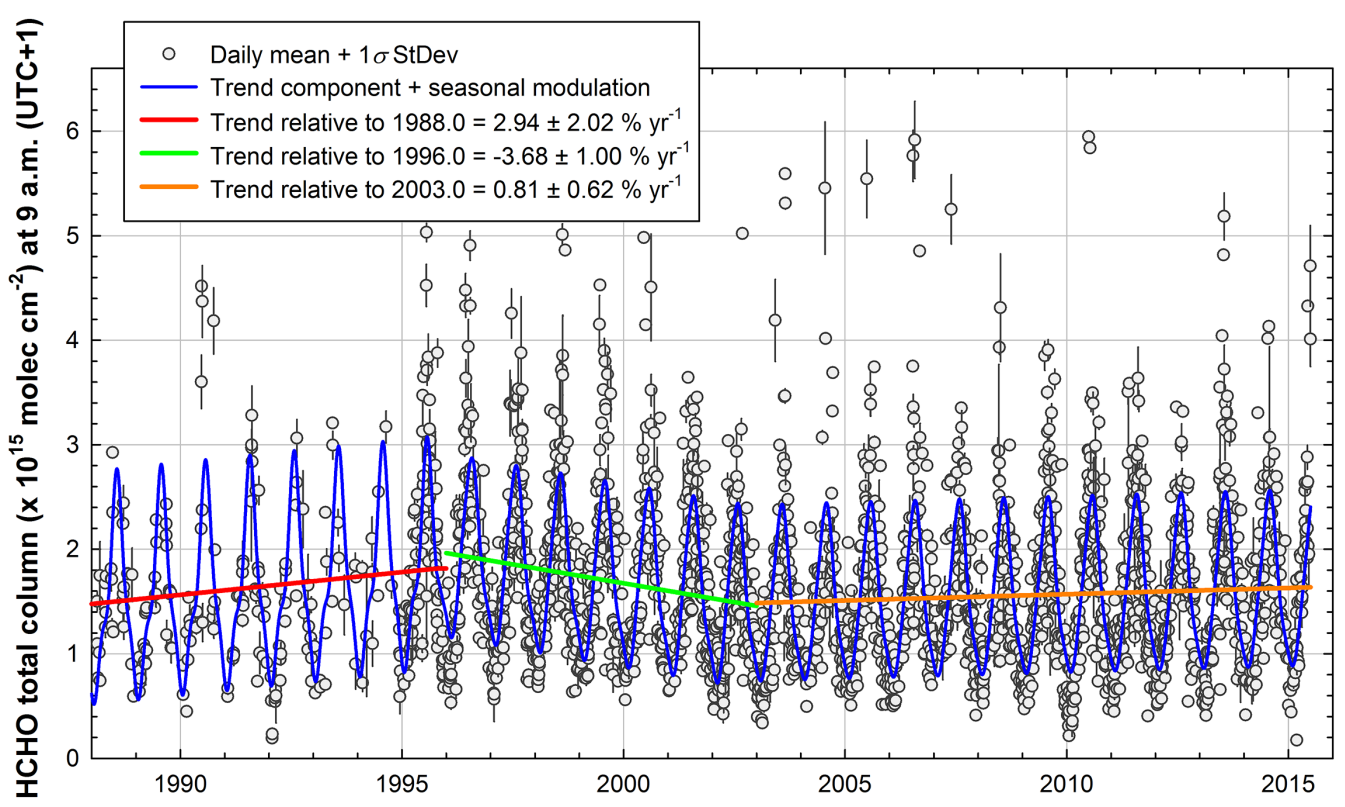

Figure 7. FTIR time series of daily mean HCHO total columns and associated $1 \sigma$ standard deviation bars above Jungfraujoch, from January 1988 to June 2015. All individual measurements have been re-scaled to 09:00 (see text) and then averaged over the days. The blue curves correspond to the functions fitted to all daily means (including trend component and seasonal modulation) by the bootstrap method of Gardiner et al. (2008), over the 1988-1995, 1996-2002 and 2003-2015/06 time periods, inclusively.

Table 2. Trends of daily mean 09:00-scaled HCHO total columns derived from the ground-based FTIR observations at the ISSJ, calculated over the 1988-1995, 1996-2002, 2003-2015 and 1996-2015 time periods by the bootstrap resampling tool. These trends are calculated using either year-round or seasonal (over DJF, MAM, JJA and SON, respectively) observations. They are expressed in annual rate of change (\% year $^{-1}$ ) relative to the $1988.0,1996.0$ and 2003.0 columns modeled by the bootstrap tool. The trends significant at the $2 \sigma$ confidence level are in boldface.

\begin{tabular}{lrrrr}
\hline Observations & $1988-1995$ & $1996-2002$ & $2003-2015$ & $1996-2015$ \\
\hline Year-round & $\mathbf{2 . 9 4} \pm \mathbf{2 . 0 2}$ & $\mathbf{- 3 . 6 8} \pm \mathbf{1 . 0 0}$ & $\mathbf{0 . 8 1} \pm \mathbf{0 . 6 2}$ & $\mathbf{- 0 . 6 1} \pm \mathbf{0 . 2 6}$ \\
Winter & $\mathbf{5 . 6 6} \pm \mathbf{5 . 0 4}$ & $0.31 \pm 2.39$ & $-0.08 \pm 1.16$ & $\mathbf{- 1 . 0 5} \pm \mathbf{0 . 5 4}$ \\
Spring & $\mathbf{4 . 9 2} \pm \mathbf{2 . 8 6}$ & $\mathbf{- 3 . 7 9} \pm \mathbf{2 . 0 5}$ & $\mathbf{1 . 9 0} \pm \mathbf{1 . 2 2}$ & $-0.3 \pm 0.52$ \\
Summer & $\mathbf{4 . 1 9} \pm \mathbf{3 . 2 9}$ & $\mathbf{- 3 . 9 1} \pm \mathbf{1 . 6 3}$ & $0.29 \pm 1.16$ & $\mathbf{- 0 . 6 5} \pm \mathbf{0 . 4 7}$ \\
Fall & $1.24 \pm 3.19$ & $\mathbf{- 2 . 9 6} \pm \mathbf{2 . 5 3}$ & $0.70 \pm 1.26$ & $-0.41 \pm 0.61$ \\
\hline
\end{tabular}

$2.55 \pm 1.75 \%$ year $^{-1}(1988-1995),-3.26 \pm 0.90 \%$ year $^{-1}$ (1996-2002) and $0.70 \pm 0.54 \%$ year $^{-1}$ (2003-2015). However, these trends may differ when calculated over specific seasons only. The corresponding results are summarized in Table 2.

The HCHO increase observed above Jungfraujoch between 1988 and 1995 may be related to the sharp rise of the atmospheric $\mathrm{CH}_{4}$ growth rate from the 1980s to the beginning of the 1990s (Nisbet et al., 2014), which is its main precursor in the background troposphere (see Sect. 4.2). Above the ISSJ, Zander et al. (2008) calculated discrete annual changes in $\mathrm{CH}_{4}$ total column derived from FTIR observations equal to 0.72 and $0.31 \%$ year $^{-1}$ for $1987-1988$ and 1995-1996, respectively. In addition, all seasons also present a significant positive rate of change of $\mathrm{HCHO}$ loadings at the $2 \sigma$ confidence level over this time period, excepting fall (see Table 2). Nonetheless, the data set covering this time range is mainly constituted of FTIR measurements recorded with the LIEGE instrument, which are sparser than those obtained with the BRUKER spectrometer from 1995 onwards (as is obvious in Fig. 7). This may explain the relatively large $2 \sigma$ confidence levels associated with the trends determined over this period. Conversely, the decreased HCHO loadings from 1996 to 2002 may be due to the global stabilization of the $\mathrm{CH}_{4}$ concentrations during most of this period (Dlugokencky, 2003), which was also observed at the ISSJ (Zander et al., 2008), combined with reduced emissions mainly from fossil fuel sources in the Northern Hemisphere (Aydin et al., 2011; Simpson et al., 2012) and short-term variations of the atmospheric $\mathrm{OH}$ burden (Montzka et al., 2011). However, it should be noted that the wintertime minimum of $\mathrm{HCHO}$ is not affected by this decrease (see Table 2). 
The observed rise of the HCHO total columns at the ISSJ during the last decade (over 2003-mid-2015), which mainly occurs during spring (see Table 2), may be explained by the highly studied global renewed increase in atmospheric $\mathrm{CH}_{4}$, starting in the mid-2000s (Kirschke et al., 2013; Nisbet et al., 2014). This renewal is also observed in the $\mathrm{CH}_{4}$ columns derived from ground-based FTIR measurements at the ISSJ. It is also worth noting that the decrease in many anthropogenic precursors of $\mathrm{HCHO}$ as a result of pollution abatements in the Northern Hemisphere has no apparent influence on the $\mathrm{HCHO}$ evolution during the last decade, probably due to the fact that the $\mathrm{HCHO}$ formation coming from these oxidized anthropogenic compounds is dominated by the methaneoriginated production, as pointed out in Sect. 4.2. Globally over the 1996-mid-2015 time period, the high-rate depletion of the HCHO loadings at the ISSJ over 1996-2002 still dominates the slow renewal from 2003 onwards: the rate of change of the HCHO burden is $-0.61 \pm 0.26 \%$ year $^{-1}$ from January 1996 to June 2015.

\section{Summary and conclusions}

In this study, we use the strategy developed by Franco et al. (2015b) to retrieve HCHO total columns from highresolution ground-based FTIR solar spectra recorded at the high-altitude station of Jungfraujoch. Because of its localization, this site allows for the study of the continental background conditions in the remote troposphere at mid-latitudes of the Northern Hemisphere. Using the large statistics that represent the January 1995-June 2015 data set of solar spectra recorded with a Bruker instrument, we first investigate the HCHO diurnal variations above the station. These variations, resulting in a.m. increases and p.m. decreases peaking around mid-day and in the early afternoon, are mainly driven by the atmospheric photochemistry, the intra-day insolation modulation and the $\mathrm{CH}_{4}$ oxidation. Then, we characterize quantitatively these monthly diurnal variations by adjusting a parametric model to the observations, consisting in a reparametrization of the standard statistical form of the Weibull continuous probability distribution of a random variable. The equation of the model and its parameters determined on the basis of the observations are provided. As this model is fully parameterized and links the daytime to the HCHO columns, it is eventually used to scale all the individual FTIR measurements on 09:00 (i.e., when the difference between the monthly intra-day regimes is minimal) in order to remove the effect of the intra-day modulation.

In the next part of the study, we perform a GEOS-Chem v9-02 simulation of the HCHO loadings above Jungfraujoch over the July 2005-May 2013 time period. As the analysis of the model outputs revealed that GEOS-Chem does not reproduce the observed diurnal variations of the $\mathrm{HCHO}$ columns, we use the daily mean 09:00-scaled FTIR measurements to compare with the simulated 09:00 total columns, accounting for the vertical resolution and sensitivity of the FTIR retrievals. Over this period, the enhanced HCHO burden simulated by GEOS-Chem v9-02 compared to version 9-01-03 reduces the mean bias with the observations, due to the implementation of the new isoprene oxidation scheme in version 9-02. Results from GEOS-Chem sensitivity runs (turning off successively either the anthropogenic, biogenic or biomass burning emissions of NMVOCs and NO implemented in the model) are also investigated and suggest that the HCHO loadings above Jungfraujoch, as well as its seasonal and inter-annual variations, are predominantly led by the atmospheric $\mathrm{CH}_{4}$ oxidation. The anthropogenic precursors of $\mathrm{HCHO}$ are estimated to contribute up to $25 \%$ to the wintertime $\mathrm{HCHO}$ total columns, while the impact of each of the other emission sources is limited to $5 \%$.

Finally, we exploit the large database of FTIR solar spectra recorded at the Jungfraujoch station by two high-resolution spectrometers spanning the 1988-1997 and 1995-2015/06 time periods, respectively. After checking the consistency between both subsets in terms of retrieved HCHO columns, we combine them in order to produce a 27 -year time series of $\mathrm{HCHO}$ total columns, which is to our best knowledge the longest time series of remote $\mathrm{HCHO}$ observations worldwide. Employing the parametric model, the intra-day variation is removed by scaling all the individual measurements of the data set to 09:00. We eventually use the so-scaled entire time series to study the long-term evolution of the $\mathrm{HCHO}$ columns in the background troposphere. Trend analysis reveals an increasing HCHO burden between 1988 and 1995 $\left(2.9 \%\right.$ year $\left.^{-1}\right)$, followed by a sharp depletion over 1996 $2002\left(-3.7 \%\right.$ year $\left.^{-1}\right)$ and a slow renewal of the growth rate from 2003 onwards $\left(0.8 \%\right.$ year $\left.^{-1}\right)$. This long-term evolution above Jungfraujoch is likely to be related to the fluctuations of the atmospheric $\mathrm{CH}_{4}$ as well as to the short-term variability of the $\mathrm{OH}$ concentrations.

Regional decadal trends at the global scale of mid-morning and early-afternoon $\mathrm{HCHO}$ columns have been recently derived from combined SCIAMACHY-GOME-2A, B and OMI measurements, respectively, over the 2004-2014 time period (De Smedt et al., 2015). Over western Europe, these trends show an overall significant decrease in the HCHO abundance (between -1.5 and $-3.0 \%$ year $^{-1}$ ), mainly attributed to effective pollution regulation measures (De Smedt et al., 2010). According to the ground-based FTIR observations, we observe by contrast a weak significant increase (less than $1 \%$ year $^{-1}$ ) of the $\mathrm{HCHO}$ total columns above the ISSJ, over approximately the same time period (2003-2015). These opposite trends may be explained by the fact that the space-borne measurements cover entire regions (more specifically Germany, France and Spain) that are largely under the influence of anthropogenic emissions of NMVOC precursors, while the Jungfraujoch HCHO columns are generally characteristic of the remote troposphere and mainly originate from the $\mathrm{CH}_{4}$ oxidation (see results in Sect. 4.2). 
Due to its very short lifetime, the abundance and spatial distribution of $\mathrm{HCHO}$ in the atmosphere can be closely related to the emissions of its NMVOC precursors and resemble their distribution in the atmosphere if the NMVOC lifetime is short enough to avoid the spatial relationship being smeared by atmospheric transport. Conversely, emissions of long-lived VOCs (such as $\mathrm{CH}_{4}$ ) will produce a global HCHO background with no detectable localized signal. As the HCHO loading above the ISSJ predominantly originates from the photochemical oxidation regimes of $\mathrm{CH}_{4}$, such inverse modeling studies will be difficult to carry out on the basis of the ground-based FTIR measurements of HCHO. Nevertheless, identifying in the Jungfraujoch time series the large HCHO columns that are due to the injection of "polluted" air masses from the planetary boundary layer (e.g., from the nearby industrialized valleys), by the use of backward trajectories models, can help in the determination of significant trends of $\mathrm{HCHO}$ according to the origin of the air masses.

As HCHO is a key component in the global catalytic cycle responsible for generating or destroying tropospheric $\mathrm{O}_{3}$ (depending on the $\mathrm{NO}_{x}$ levels), monitoring and understanding of the $\mathrm{HCHO}$ evolution for background conditions are of primary importance. Indeed, many questions arise as regards the renewed increase in atmospheric $\mathrm{CH}_{4}$, the main precursor of $\mathrm{HCHO}$ in the remote troposphere. According to Stickler et al. (2006) and Fried et al. (2008), oxidized $\mathrm{CH}_{4}$ still represents an important source of $\mathrm{HCHO}$ production in the uppermost tropospheric layers, with contributions that vary from 40 to more than $50 \%$, depending on the air masses. More particularly, a sharp increase in the ethane $\left(\mathrm{C}_{2} \mathrm{H}_{6}\right)$ burden of close to $5 \%$ year $^{-1}$ since 2009 , attributed to the massive growth of shale gas exploitation in North America, has recently been highlighted above Jungfraujoch (Franco et al., 2015a). Therefore, as $\mathrm{C}_{2} \mathrm{H}_{6}$ is a $\mathrm{HCHO}$ precursor and shares most of its sources with $\mathrm{CH}_{4}$, there are some concerns as to the impact on the evolution of the HCHO loadings. Groundbased FTIR measurements combined with model simulations can undoubtedly help with these issues.

The parametric model implemented in this study and the quantitative characterization of the monthly intra-day variations of HCHO may be a very useful tool in future works dedicated to the comparison between ground-based FTIR and space-borne HCHO measurements. Indeed, long-term consistent data sets of regular HCHO observations are increasingly required for calibration/validation efforts of present satellite instruments such as OMI and GOME-2. Furthermore, from 2017 onwards, the space-borne monitoring observations are planned to continue with TROPOMI (TROPOspheric Monitoring Instrument) and a third GOME-2 instrument. By scaling the FTIR HCHO columns to the respective overpass times of the satellite sensors, this parametric model applied to the Jungfraujoch long-term time series may be of high value for future validation/calibration tasks in remote conditions at mid-latitudes of the Northern Hemisphere. In the future, it will be useful to evaluate the uncertainty associ- ated with the scaling of the FTIR columns via the parametric model. However, we anticipate that it will be far below the random error inherent to the retrieval of individual $\mathrm{HCHO}$ total columns ( $21 \%$; see Franco et al., 2015b). The parameters of the fitting model are made available as Table S1 in the Supplement.

\section{The Supplement related to this article is available online at doi:10.5194/acp-16-4171-2016-supplement.}

Acknowledgements. The University of Liège contribution has been primarily supported by PRODEX project ACROSAT funded by the Belgian Science Policy Office (BELSPO). The F.R.S.-FNRS and the Fédération Wallonie Bruxelles contributed to observational activities support. The Swiss GAW-CH program is further acknowledged. Emmanuel Mahieu is a research associate with F.R.S.-FNRS. We are grateful to the International Foundation High Altitude Research Stations Jungfraujoch and Gornergrat (HFSJG, Bern) for supporting the facilities needed to perform the observations. We further acknowledge the vital contribution from all the Belgian colleagues in performing the Jungfraujoch FTIR observations, among them Philippe Demoulin for recording all the home-made spectra used here. This research was also financially supported at ULg by EU 7th Framework Programme projects NORS (contract 284421) and AGACC-II (BELSPO, Brussels).

Edited by: M. Van Roozendael

\section{References}

Anderson, L. G., Lanning, J. A., Barrell, R., Miyagishima, J., Jones, R. H., and Wolfe, P.: Sources and sinks of formaldehyde and acetaldehyde: An analysis of Denver's ambient concentration data, Atmos. Environ., 30, 2113-2123, doi:10.1016/13522310(95)00175-1, 1996.

Atkinson, R.: Atmospheric chemistry of VOCs and $\mathrm{NO}_{x}$, Atmos. Environ., 34, 2063-2101, doi:10.1016/S1352-2310(99)00460-4, 2000.

Aydin, M., Verhulst, K. R., Saltzman, E. S., Battle, M. O., Montzka, S. A., Blake, D. R., Tang, Q., and Prather, M. J.: Recent decreases in fossil-fuel emissions of ethane and methane derived from firn air, Nature, 476, 198-201, doi:10.1038/nature10352, 2011.

Balzani Lööv, J. M., Henne, S., Legreid, G., Staehelin, J., Reimann, S., Prévôt, A. S. H., Steinbacher, M., and Vollmer, M. K.: Estimation of background concentrations of trace gases at the Swiss Alpine site Jungfraujoch (3580 ma.s.1.), J. Geophys. Res., 113, D22305, doi:10.1029/2007JD009751, 2008.

Bey, I., Jacob, D. J., Yantosca, R. M., Logan, J. A., Field, B. D., Fiore, A. M., Li, Q., Liu, H. Y., Mickley, L. J., and Schultz, M. G.: Global modeling of tropospheric chemistry with assimilated meteorology: model description and evaluation, J. Geophys. Res.-Atmos., 106, 23073-23095, doi:10.1029/2001JD000807, 2001. 
Calvert, J. G., Atkinson, R., Kerr, J. A., Madronich, S., Moortgat, G. K., Wallington, T. J., and Yarwood, G. (Eds.): The mechanisms of atmospheric oxidation of the alkenes, Oxford University Press, New York, 552 p., 2000.

Cantrell, C. A., Davidson, J. A., McDaniel, A. H., Shetter, R. E., and Calvert, J. G.: Temperature-dependent formaldehyde cross sections in the near-ultraviolet spectral region, J. Phys. Chem., 94, 3902-3908, doi:10.1021/j100373a008, 1990.

Carlier, P., Hannachi, H., and Mouvier, G.: The chemistry of carbonyl compounds in the atmosphere: A review, Atmos. Environ., 20, 2079-2099, doi:10.1016/0004-6981(86)90304-5, 1986.

Chance, K., Palmer, P. I., Spurr, R. J. D., Martin, R. V., Kurosu, T. P., and Jacob, D. J.: Satellite observations of formaldehyde over North America from GOME, Geophys. Res. Lett., 27, 34613464, doi:10.1029/2000GL011857, 2000.

Chang, L., Palo, S., Hagan, M., Richter, J., Garcia, R., Riggin, D., and Fritts, D.: Structure of the migrating diurnal tide in the Whole Atmosphere Community Climate Model (WACCM), Adv. Space Res., 41, 1398-1407, doi:10.1016/j.asr.2007.03.035, 2008.

Choi, W., Faloona, I. C., Bouvier-Brown, N. C., McKay, M., Goldstein, A. H., Mao, J., Brune, W. H., LaFranchi, B. W., Cohen, R. C., Wolfe, G. M., Thornton, J. A., Sonnenfroh, D. M., and Millet, D. B.: Observations of elevated formaldehyde over a forest canopy suggest missing sources from rapid oxidation of arboreal hydrocarbons, Atmos. Chem. Phys., 10, 8761-8781, doi:10.5194/acp-10-8761-2010, 2010.

de Serves, C.: Gas phase formaldehyde and peroxide measurements in the Arctic atmosphere, J. Geophys. Res., 99, 25391-25398, doi:10.1029/94JD00547, 1994.

De Smedt, I., Stavrakou, T., Müller, J.-F., van der A. R. J., and Van Roozendael, M.: Trend detection in satellite observations of formaldehyde tropospheric columns, Geophys. Res. Lett., 37, L18808, doi:10.1029/2010GL044245, 2010.

De Smedt, I., Stavrakou, T., Hendrick, F., Danckaert, T., Vlemmix, T., Pinardi, G., Theys, N., Lerot, C., Gielen, C., Vigouroux, C., Hermans, C., Fayt, C., Veefkind, P., Müller, J.-F., and Van Roozendael, M.: Diurnal, seasonal and long-term variations of global formaldehyde columns inferred from combined OMI and GOME-2 observations, Atmos. Chem. Phys., 15, 12519-12545, doi:10.5194/acp-15-12519-2015, 2015.

DiGangi, J. P., Boyle, E. S., Karl, T., Harley, P., Turnipseed, A., Kim, S., Cantrell, C., Maudlin III, R. L., Zheng, W., Flocke, F., Hall, S. R., Ullmann, K., Nakashima, Y., Paul, J. B., Wolfe, G. M., Desai, A. R., Kajii, Y., Guenther, A., and Keutsch, F. N.: First direct measurements of formaldehyde flux via eddy covariance: implications for missing in-canopy formaldehyde sources, Atmos. Chem. Phys., 11, 10565-10578, doi:10.5194/acp-11-10565-2011, 2011.

DiGangi, J. P., Henry, S. B., Kammrath, A., Boyle, E. S., Kaser, L., Schnitzhofer, R., Graus, M., Turnipseed, A., Park, J-H., Weber, R. J., Hornbrook, R. S., Cantrell, C. A., Maudlin III, R. L., Kim, S., Nakashima, Y., Wolfe, G. M., Kajii, Y., Apel, E. C., Goldstein, A. H., Guenther, A., Karl, T., Hansel, A., and Keutsch, F. N.: Observations of glyoxal and formaldehyde as metrics for the anthropogenic impact on rural photochemistry, Atmos. Chem. Phys., 12, 9529-9543, doi:10.5194/acp-12-95292012, 2012.

Dils, B., Cui, J., Henne, S., Mahieu, E., Steinbacher, M., and De Mazière, M.: 1997-2007 CO trend at the high Alpine site
Jungfraujoch: a comparison between NDIR surface in situ and FTIR remote sensing observations, Atmos. Chem. Phys., 11, 6735-6748, doi:10.5194/acp-11-6735-2011, 2011.

Dufour, G., Szopa, S., Barkley, M. P., Boone, C. D., Perrin, A., Palmer, P. I., and Bernath, P. F.: Global uppertropospheric formaldehyde: seasonal cycles observed by the ACE-FTS satellite instrument, Atmos. Chem. Phys., 9, 38933910, doi:10.5194/acp-9-3893-2009, 2009a.

Dufour, G., Wittrock, F., Camredon, M., Beekmann, M., Richter, A., Aumont, B., and Burrows, J. P.: SCIAMACHY formaldehyde observations: constraint for isoprene emission estimates over Europe?, Atmos. Chem. Phys., 9, 1647-1664, doi:10.5194/acp-91647-2009, 2009b.

Dlugokencky, E. J.: Atmospheric methane levels off: temporary pause or a new steady-state?, Geophys. Res. Lett., 30, 1992, doi:10.1029/2003GL018126, 2003.

Franco, B., Bader, W., Toon, G. C., Bray, C., Perrin, A., Fischer, E. V., Sudo, K., Boone, C. D., Bovy, B., Lejeune, B., Servais, C., and Mahieu, E.: Retrieval of ethane from ground-based FTIR solar spectra using improved spectroscopy: recent burden increase above Jungfraujoch, J. Quant. Spectrosc. Ra., 160, 3649, doi:10.1016/j.jqsrt.2015.03.017, 2015a.

Franco, B., Hendrick, F., Van Roozendael, M., Müller, J.-F., Stavrakou, T., Marais, E. A., Bovy, B., Bader, W., Fayt, C., Hermans, C., Lejeune, B., Pinardi, G., Servais, C., and Mahieu, E.: Retrievals of formaldehyde from ground-based FTIR and MAXDOAS observations at the Jungfraujoch station and comparisons with GEOS-Chem and IMAGES model simulations, Atmos. Meas. Tech., 8, 1733-1756, doi:10.5194/amt-8-1733-2015, 2015b.

Fried, A., Lee, Y.-N., Frost, G., Wert, B., Henry, B., Drummond, J. R., Hübler, G., and Jobson, T.: Airborne $\mathrm{CH}_{2} \mathrm{O}$ measurements over the North Atlantic during the 1997 NARE campaign: instrument comparisons and distributions, J. Geophys. Res.-Atmos., 107, 4039, doi:10.1029/2000JD000260, 2002.

Fried, A., Olson, J. R., Walega, J. G., Crawford, J. H., Chen, G., Weibring, P., Richter, D., Roller, C., Tittel, F., Porter, M., Fuelberg, H., Halland, J., Bertram, T. H., Cohen, R. C., Pickering, K., Heikes, B. G., Snow, J. A., Shen, H., O’Sullivan, D. W., Brune, W. H., Ren, X., Blake, D. R., Blake, N., Sachse, G., Diskin, G. S., Podolske, J., Vay, S. A., Shetter, R. E., Hall, S. R., Anderson, B. E., Thornhill, L., Clark, A. D., McNaughton, C. S., Singh, H. B., Avery, M. A., Huey, G., Kim, S., and Millet, D. B.: Role of convection in redistributing formaldehyde to the Upper Troposphere over North America and the North Atlantic during the Summer 2004 INTEX campaign, J. Geophys. Res., 113, D17306, doi:10.1029/2007JD009760, 2008.

Fried, A., Cantrell, C., Olson, J., Crawford, J. H., Weibring, P., Walega, J., Richter, D., Junkermann, W., Volkamer, R., Sinreich, R., Heikes, B. G., O’Sullivan, D., Blake, D. R., Blake, N., Meinardi, S., Apel, E., Weinheimer, A., Knapp, D., Perring, A., Cohen, R. C., Fuelberg, H., Shetter, R. E., Hall, S. R., Ullmann, K., Brune, W. H., Mao, J., Ren, X., Huey, L. G., Singh, H. B., Hair, J. W., Riemer, D., Diskin, G., and Sachse, G.: Detailed comparisons of airborne formaldehyde measurements with box models during the 2006 INTEX-B and MILAGRO campaigns: potential evidence for significant impacts of unmeasured and multi-generation volatile organic carbon compounds, 
Atmos. Chem. Phys., 11, 11867-11894, doi:10.5194/acp-1111867-2011, 2011

Frost, G. J., Fried, A., Lee, Y.-N., Wert, B., Henry, B., Drummond, J. R., Evans, M. J., Fehsenfeld, F. C., Goldan, P. D., Holloway, J. S., Hübler, G., Jakoubek, R., Jobson, B. T., Knapp, K., Kuster, W. C., Roberts, J., Rudolph, J., Ryerson, T. B., Stohl, A., Stroud, C., Sueper, D. T., Trainer, M., and Williams, J.: Comparisons of box model calculations and measurements of formaldehyde from the 1997 North Atlantic Regional Experiment, J. Geophys. Res., 107, 4060, doi:10.1029/2001JD000896, 2002.

Fu, T.-M., Jacob, D. J., Palmer, P. I., Chance, K., Wang, Y. X., Barletta, B., Blake, D. R., Stanton, J. C., and Pilling, M. J.: Space-based formaldehyde measurements as constraints on volatile organic compound emissions in east and south Asia and implications for ozone, J. Geophys. Res., 112, D06312, doi:10.1029/2006JD007853, 2007.

Gardiner, T., Forbes, A., de Mazière, M., Vigouroux, C., Mahieu, E., Demoulin, P., Velazco, V., Notholt, J., Blumenstock, T., Hase, F., Kramer, I., Sussmann, R., Stremme, W., Mellqvist, J., Strandberg, A., Ellingsen, K., and Gauss, M.: Trend analysis of greenhouse gases over Europe measured by a network of ground-based remote FTIR instruments, Atmos. Chem. Phys., 8, 6719-6727, doi:10.5194/acp-8-6719-2008, 2008.

Guenther, A., Karl, T., Harley, P., Wiedinmyer, C., Palmer, P. I., and Geron, C.: Estimates of global terrestrial isoprene emissions using MEGAN (Model of Emissions of Gases and Aerosols from Nature), Atmos. Chem. Phys., 6, 3181-3210, doi:10.5194/acp-63181-2006, 2006.

Guenther, A. B., Jiang, X., Heald, C. L., Sakulyanontvittaya, T., Duhl, T., Emmons, L. K., and Wang, X.: The Model of Emissions of Gases and Aerosols from Nature version 2.1 (MEGAN2.1): an extended and updated framework for modeling biogenic emissions, Geosci. Model Dev., 5, 1471-1492, doi:10.5194/gmd-51471-2012, 2012.

Hak, C., Pundt, I., Trick, S., Kern, C., Platt, U., Dommen, J., Ordóñez, C., Prévôt, A. S. H., Junkermann, W., AstorgaLloréns, C., Larsen, B. R., Mellqvist, J., Strandberg, A., Yu, Y., Galle, B., Kleffmann, J., Lörzer, J. C., Braathen, G. O., and Volkamer, R.: Intercomparison of four different in-situ techniques for ambient formaldehyde measurements in urban air, Atmos. Chem. Phys., 5, 2881-2900, doi:10.5194/acp-5-2881-2005, 2005.

Heckel, A., Richter, A., Tarsu, T., Wittrock, F., Hak, C., Pundt, I., Junkermann, W., and Burrows, J. P.: MAX-DOAS measurements of formaldehyde in the Po-Valley, Atmos. Chem. Phys., 5, 909918, doi:10.5194/acp-5-909-2005, 2005.

Herndon, S. C., Jayne, J. T., Zahniser, M. S., Worsnop, D. R., Knighton, B., Alwine, E., Lamb, B. K., Zavala, M., Nelson, D. D., McManus, J. B., Shorter, J. H., Canagaratnam, M. R., Onasch, T. B., and Kolb, C. E.: Characterization of urban pollutant emission fluxes and ambient concentration distributions using a mobile laboratory with rapid response instrumentation, Faraday Discuss., 130, 327-339, doi:10.1039/B500411J, 2005.

Houweling, S., Dentener, F., and Lelieveld, J.: The impact of nonmethane hydrocarbon compounds on tropospheric photochemistry, J. Geophys. Res.-Atmos., 103, 10673-10696, doi:10.1029/97JD03582, 1998.

Inomata, S., Tanimoto, H., Kameyama, S., Tsunogai, U., Irie, H., Kanaya, Y., and Wang, Z.: Technical Note: Determination of formaldehyde mixing ratios in air with PTR-MS: laboratory experiments and field measurements, Atmos. Chem. Phys., 8, 273 284, doi:10.5194/acp-8-273-2008, 2008.

Irie, H., Takashima, H., Kanaya, Y., Boersma, K. F., Gast, L., Wittrock, F., Brunner, D., Zhou, Y., and Van Roozendael, M.: Eightcomponent retrievals from ground-based MAX-DOAS observations, Atmos. Meas. Tech., 4, 1027-1044, doi:10.5194/amt-41027-2011, 2011.

Jones, N. B., Riedel, K., Allan, W., Wood, S., Palmer, P. I., Chance, K., and Notholt, J.: Long-term tropospheric formaldehyde concentrations deduced from ground-based fourier transform solar infrared measurements, Atmos. Chem. Phys., 9, 7131-7142, doi:10.5194/acp-9-7131-2009, 2009.

Junkermann, W.: On the distribution of formaldehyde in the western Po-Valley, Italy, during FORMAT 2002/2003, Atmos. Chem. Phys., 9, 9187-9196, doi:10.5194/acp-9-9187-2009, 2009.

Kanakidou, M., Seinfeld, J. H., Pandis, S. N., Barnes, I., Dentener, F. J., Facchini, M. C., Van Dingenen, R., Ervens, B., Nenes, A., Nielsen, C. J., Swietlicki, E., Putaud, J. P., Balkanski, Y., Fuzzi, S., Horth, J., Moortgat, G. K., Winterhalter, R., Myhre, C. E. L., Tsigaridis, K., Vignati, E., Stephanou, E. G., and Wilson, J.: Organic aerosol and global climate modelling: a review, Atmos. Chem. Phys., 5, 1053-1123, doi:10.5194/acp-51053-2005, 2005.

Kirschke, S., Bousquet, P., Ciais, P., Saunois, M., Canadell, J. G., Dlugokencky, E. J., Bergamaschi, P., Bergmann, D., Blake, D. R., Bruhwiler, L., Cameron-Smith, P., Castaldi, S., Chevallier, F., Feng, L., Fraser, A., Heimann, M., Hodson, E. L., Houweling, S., Josse, B., Fraser, P. J., Krummel, P. B., Lamarque, J.-F., Langenfelds, R. L., Le Quéré, C., Naik, V., O’Doherty, S., Palmer, P. I., Pison, I., Plummer, D., Poulter, B., Prinn, R. G., Rigby, M., Ringeval, B., Santini, M., Schmidt, M., Shindell, D. T., Simpson, I. J., Spahni, R., Steele, L. P., Strode, S. A., Sudo, K., Szopa, S., van der Werf, G. R., Voulgarakis, A., van Weele, M., Weiss, R. F., Williams, J. E., and Zeng, G.: Three decades of global methane sources and sinks, Nat. Geosci., 6, 813-823, doi:10.1038/ngeo1955, 2013.

Lee, M., Heikes, B. G., Jacob, D. J., Sachse, G., and Anderson, B.: Hydrogen peroxide, organic hydroperoxide, and formaldehyde as primary pollutants from biomass burning, J. Geophys. Res., 102, 1301-1309, doi:10.1029/96JD01709, 1997.

Legreid, G., Folini, D., Staehelin, J., Balzani Lööv, J., Steinbacher, M., and Reimann, S.: Measurements of organic trace gases including oxygenated volatile organic compounds at the high alpine site Jungfraujoch (Switzerland): seasonal variation and source allocations, J. Geophys. Res., 113, D05307, doi:10.1029/2007JD008653, 2008.

Logan, J. A., Prather, M. J., Wofsy, S. C., and McElroy, M. B.: Tropospheric chemistry: a global perspective, J. Geophys. Res., 86, 7210-7254, doi:10.1029/JC086iC08p07210, 1981.

Luecken, D. J., Hutzell, W. T., Strum, M. L., and Pouliot, G. A.: Regional sources of atmospheric formaldehyde and acetaldehyde, and implications for atmospheric modeling, Atmos. Environ., 47, 477-490, doi:10.1016/j.atmosenv.2011.10.005, 2012.

MacDonald, S. M., Oetjen, H., Mahajan, A. S., Whalley, L. K., Edwards, P. M., Heard, D. E., Jones, C. E., and Plane, J. M. C.: DOAS measurements of formaldehyde and glyoxal above a south-east Asian tropical rainforest, Atmos. Chem. Phys., 12, 5949-5962, doi:10.5194/acp-12-5949-2012, 2012. 
Mahieu, E., Zander, R., Delbouille, L., Demoulin, P., Roland, G., and Servais, C.: Observed trends in total vertical column abundances of atmospheric gases from IR solar spectra recorded at the Jungfraujoch, J. Atmos. Chem., 28, 227-243, doi:10.1023/A:1005854926740, 1997.

Mao, J., Jacob, D. J., Evans, M. J., Olson, J. R., Ren, X., Brune, W. H., Clair, J. M. St., Crounse, J. D., Spencer, K. M., Beaver, M. R., Wennberg, P. O., Cubison, M. J., Jimenez, J. L., Fried, A., Weibring, P., Walega, J. G., Hall, S. R., Weinheimer, A. J., Cohen, R. C., Chen, G., Crawford, J. H., McNaughton, C., Clarke, A. D., Jaeglé, L., Fisher, J. A., Yantosca, R. M., Le Sager, P., and Carouge, C.: Chemistry of hydrogen oxide radicals $\left(\mathrm{HO}_{x}\right)$ in the Arctic troposphere in spring, Atmos. Chem. Phys., 10, 5823-5838, doi:10.5194/acp-10-58232010, 2010.

Mao, J., Paulot, F., Jacob, D. J., Cohen, R. C., Crounse, J. D., Wennberg, P. O., Keller, C. A., Hudman, R. C., Barkley, M. P., and Horowitz, L. W.: Ozone and organic nitrates over the eastern United States: Sensitivity to isoprene chemistry, J. Geophys. Res.-Atmos., 118, 11, 256-268, doi:10.1002/jgrd.50817, 2013.

Marais, E. A., Jacob, D. J., Kurosu, T. P., Chance, K., Murphy, J. G., Reeves, C., Mills, G., Casadio, S., Millet, D. B., Barkley, M. P., Paulot, F., and Mao, J.: Isoprene emissions in Africa inferred from OMI observations of formaldehyde columns, Atmos. Chem. Phys., 12, 6219-6235, doi:10.5194/acp12-6219-2012, 2012.

Marais, E. A., Jacob, D. J., Guenther, A., Chance, K., Kurosu, T. P., Murphy, J. G., Reeves, C. E., and Pye, H. O. T.: Improved model of isoprene emissions in Africa using Ozone Monitoring Instrument (OMI) satellite observations of formaldehyde: implications for oxidants and particulate matter, Atmos. Chem. Phys., 14, 7693-7703, doi:10.5194/acp-14-7693-2014, 2014.

Marquardt, D. W.: An Algorithm for Least-Squares Estimation of Nonlinear Parameters, J. Soc. Indust. Appl. Math., 11, 431-441, doi:10.1137/0111030, 1963.

Millet, D. B., Jacob, D. J., Boersma, K. F., Fu, T. M., Kurosu, T. P., Chance, K., Heald, C. L., and Guenther, A.: Spatial distribution of isoprene emissions from North America derived from formaldehyde column measurements by the OMI satellite sensor, J. Geophys. Res., 113, D02307, doi:10.1029/2007JD008950, 2008.

Montzka, S. A., Krol, M., Dlugokencky, E., Hall, B., Jockel, P., and Lelieveld, J.: Small interannual variability of global atmospheric hydroxyl, Science, 331, 67-69, doi:10.1126/science.1197640, 2011.

Nisbet, E. G., Dlugokencky, E. J., and Bousquet, P.: Atmospheric science. Methane on the rise-again, Science, 343, 493-495, doi:10.1126/science.1247828, 2014.

Notholt, J., Toon, G., Stordal, F., Solberg, S., Schmidbauer, N., Becker, E., Meier, A., and Sen, B.: Seasonal variations of atmospheric trace gases in the high Arctic at $79^{\circ}$ N, J. Geophys. Res., 102, 12855-12861, doi:10.1029/97JD00337, 1997.

Palmer, P. I., Jacob, D. J., Fiore, A. M., Martin, R. V., Chance, K., and Kurosu, T. P.: Mapping isoprene emissions over North America using formaldehyde column observations from space, J. Geophys. Res., 108, 4180, doi:10.1029/2002JD002153, 2003.

Palmer, P. I., Abbot, D. S., Fu, T.-M., Jacob, D. J., Chance, K., Kurosu, T. P., Guenther, A., Wiedinmyer, C., Stanton, J. C., Pilling, M. J., Pressley, S. N., Lamb, B., and Sumner, A. L.:
Quantifying the seasonal and interannual variability of North American isoprene emissions using satellite observations of the formaldehyde column, J. Geophys. Res., 111, D12315, doi:10.1029/2005JD006689, 2006.

Park, R. J., Jacob, D. J., Field, B. D., Yantosca, R. M., and Chin, M.: Natural and transboundary pollution influences on sulfate-nitrate-ammonium aerosols in the United States: implications for policy, J. Geophys. Res., 109, D15204, doi:10.1029/2003JD004473, 2004.

Paton-Walsh, C., Deutscher, N. M., Griffith, D. W. T., Forgan, B. W., Wilson, S. R., Jones, N. B., and Edwards, D. P.: Trace gas emissions from savanna fires in Northern Australia, J. Geophys. Res., 115, D16314, doi:10.1029/2009JD013309, 2010.

Paulot, F., Crounse, J. D., Kjaergaard, H. G., Kroll, J. H., Seinfeld, J. H., and Wennberg, P. O.: Isoprene photooxidation: new insights into the production of acids and organic nitrates, Atmos. Chem. Phys., 9, 1479-1501, doi:10.5194/acp-9-1479-2009, 2009a.

Paulot, F., Crounse, J. D., Kjaergaard, H. G., Kürten, A., St Clair, J. M., Seinfeld, J. H., and Wennberg, P. O.: Unexpected epoxide formation in the gas-phase photo-oxidation of isoprene, Science, 325, 730-733, doi:10.1126/science.1172910, $2009 \mathrm{~b}$.

Peters, E., Wittrock, F., Großmann, K., Frieß, U., Richter, A., and Burrows, J. P.: Formaldehyde and nitrogen dioxide over the remote western Pacific Ocean: SCIAMACHY and GOME-2 validation using ship-based MAX-DOAS observations, Atmos. Chem. Phys., 12, 11179-11197, doi:10.5194/acp-12-111792012, 2012.

Pfister, G. G., Emmons, L. K., Hess, P. G., Lamarque, J.-F., Orlando, J. J., Walters, S., Guenther, A., Palmer, P. I., and Lawrence, P. J.: Contribution of isoprene to chemical budgets: A model tracer study with the NCAR CTM MOZART-4, J. Geophys. Res., 113, D05308, doi:10.1029/2007JD008948, 2008.

Pikelnaya, O., Hurlock, S. C., Trick, S., and Stutz, J.: Intercomparison of multiaxis and long-path optical absorption spectroscopy measurements in the marine boundary layer, J. Geophys. Res., 112, D10S01, doi:10.1029/2006JD007727, 2007.

Pinardi, G., Van Roozendael, M., Abuhassan, N., Adams, C., Cede, A., Clémer, K., Fayt, C., Frieß, U., Gil, M., Herman, J., Hermans, C., Hendrick, F., Irie, H., Merlaud, A., Navarro Comas, M., Peters, E., Piters, A. J. M., Puentedura, O., Richter, A., Schönhardt, A., Shaiganfar, R., Spinei, E., Strong, K., Takashima, H., Vrekoussis, M., Wagner, T., Wittrock, F., and Yilmaz, S.: MAX-DOAS formaldehyde slant column measurements during CINDI: intercomparison and analysis improvement, Atmos. Meas. Tech., 6, 167-185, doi:10.5194/amt-6-167-2013, 2013.

Possanzini, M., Di Palo, V., and Ceccinato, A.: Sources and photodecomposition of formaldehyde and acetaldehyde in Rome ambient air, Atmos. Environ., 36, 3195-3201, doi:10.1016/S13522310(02)00192-9, 2002.

Rinsland, C. P., Jones, N. B., Connor, B. J., Logan, J. A., Pougatchev, N. S., Goldman, A., Murcray, F. J., Stephen, T. M., Pine, A. S., Zander, R., Mahieu, E., and Demoulin, P.: Northern and Southern Hemisphere ground-based infrared spectroscopic measurements of tropospheric carbon monoxide and ethane, J. Geophys. Res., 103, 28197-28217, doi:10.1029/98JD02515, 1998. 
Rodgers, C. D.: Inverse Methods for Atmospheric Sounding: Theory and Practice, Series on Atmospheric, Oceanic and Planetary Physics, Vol. 2, World Scientific Publishing Co., Singapore, 2000.

Rodgers, C. D. and Connor, B. J.: Intercomparison of remote sounding instruments, J. Geophys. Res., 108, 4116-4129, doi:10.1029/2002JD002299, 2003.

Rothman, L. S., Gordon, I. E., Barbe, A., Benner, D. C., Bernath, P. F., Birk, M., Boudon, V., Brown, L. R., Campargue, A., Champion, J.-P., Chance, K., Coudert, L. H., Danaj, V., Devi, V. M., Fally, S., Flaud, J.-M., Gamache, R. R., Goldmanm, A., Jacquemart, D., Kleiner, I., Lacome, N., Lafferty, W. J., Mandin, J.-Y., Massie, S. T., Mikhailenko, S. N., Miller, C. E., Moazzen-Ahmadi, N., Naumenko, O. V., Nikitin, A. V., Orphal, J., Perevalov, V. I., Perrin, A., PredoiCross, A., Rinsland, C. P., Rotger, M., Simeckova, M., Smith, M. A. H., Sung, K., Tashkun, S. A., Tennyson, J., Toth, R. A., Vandaele, A. C., and Vander Auwera, J.: The Hitran 2008 molecular spectroscopic database, J. Quant. Spectrosc. Ra., 110, 533-572, doi:10.1016/j.jqsrt.2009.02.013, 2009.

Simpson, D., Michael Gauss, S. T., and Valdebenito, A.: Model Updates Transboundary Acidification, Eutrophication and Ground Level Ozone in Europe EMEP Status Report 1/2010, The Norwegian Meteorological Institute, Oslo, Norway, 2010.

Simpson, I. J., Sulbaek Andersen, M. P., Meinardi, S., Bruhwiler, L., Blake, N. J., Helmig, D., Rowland, F. S., and Blake, D. R.: Long-term decline of global atmospheric ethane concentrations and implications for methane, Nature, 488, 490-494, doi:10.1038/nature11342, 2012.

Staffelbach, T., Neftel, A., Stauffer, B., and Jacob, D. J.: A record of the atmospheric methane sink from formaldehyde in polar ice cores, Nature, 349, 603-605, doi:10.1038/349603a0, 1991.

Starokozhev, E., Fries, E., Cycura, A., and Püttmann, W.: Distribution of VOCs between air and snow at the Jungfraujoch high alpine research station, Switzerland, during CLACE 5 (winter 2006), Atmos. Chem. Phys., 9, 3197-3207, doi:10.5194/acp-93197-2009, 2009.

Stavrakou, T., Müller, J.-F., De Smedt, I., Van Roozendael, M., van der Werf, G. R., Giglio, L., and Guenther, A.: Global emissions of non-methane hydrocarbons deduced from SCIAMACHY formaldehyde columns through 2003-2006, Atmos. Chem. Phys., 9, 3663-3679, doi:10.5194/acp-9-3663-2009, 2009a.

Stavrakou, T., Müller, J.-F., De Smedt, I., Van Roozendael, M., van der Werf, G. R., Giglio, L., and Guenther, A.: Evaluating the performance of pyrogenic and biogenic emission inventories against one decade of space-based formaldehyde columns, Atmos. Chem. Phys., 9, 1037-1060, doi:10.5194/acp-9-1037-2009, 2009 b.

Stavrakou, T., Müller, J.-F., Boersma, K. F., van der A, R. J., Kurokawa, J., Ohara, T., and Zhang, Q.: Key chemical $\mathrm{NO}_{x}$ sink uncertainties and how they influence top-down emissions of nitrogen oxides, Atmos. Chem. Phys., 13, 9057-9082, doi:10.5194/acp-13-9057-2013, 2013.

Stavrakou, T., Müller, J.-F., Bauwens, M., De Smedt, I., Van Roozendael, M., De Mazière, M., Vigouroux, C., Hendrick, F., George, M., Clerbaux, C., Coheur, P.-F., and Guenther, A.: How consistent are top-down hydrocarbon emissions based on formaldehyde observations from GOME-2 and OMI?, Atmos.
Chem. Phys., 15, 11861-11884, doi:10.5194/acp-15-118612015, 2015.

Stickler, A., Fischer, H., Williams, J., de Reus, M., Sander, R., Lawrence, M. G., Crowley, J. N., and Lelieveld, J.: Influence of summertime deep convection on formaldehyde in the middle and upper troposphere over Europe, J. Geophys. Res., 111, D14308, doi:10.1029/2005JD007001, 2006.

van der Werf, G. R., Randerson, J. T., Giglio, L., Collatz, G. J., Mu, M., Kasibhatla, P. S., Morton, D. C., DeFries, R. S., Jin, Y., and van Leeuwen, T. T.: Global fire emissions and the contribution of deforestation, savanna, forest, agricultural, and peat fires (1997-2009), Atmos. Chem. Phys., 10, 11707-11735, doi:10.5194/acp-10-11707-2010, 2010.

van Donkelaar, A., Martin, R. V., Leaitch, W. R., Macdonald, A. M., Walker, T. W., Streets, D. G., Zhang, Q., Dunlea, E. J., Jimenez, J. L., Dibb, J. E., Huey, L. G., Weber, R., and Andreae, M. O.: Analysis of aircraft and satellite measurements from the Intercontinental Chemical Transport Experiment (INTEX-B) to quantify long-range transport of East Asian sulfur to Canada, Atmos. Chem. Phys., 8, 2999-3014, doi:10.5194/acp8-2999-2008, 2008.

Van het Bolscher, M., Pereira, J., Spessa, A., Dalsoren, S., van Nojie, T., and Szopa, S.: REanalysis of the TROpospheric Chemical Composition Over the Past 40 years, Hamburg, Germany, Max Plank Institute for Meteorology, 2008.

Viatte, C., Strong, K., Walker, K. A., and Drummond, J. R.: Five years of $\mathrm{CO}, \mathrm{HCN}, \mathrm{C}_{2} \mathrm{H}_{6}, \mathrm{C}_{2} \mathrm{H}_{2}, \mathrm{CH}_{3} \mathrm{OH}, \mathrm{HCOOH}$ and $\mathrm{H}_{2} \mathrm{CO}$ total columns measured in the Canadian high Arctic, Atmos. Meas. Tech., 7, 1547-1570, doi:10.5194/amt-7-1547-2014, 2014.

Vigouroux, C., Hendrick, F., Stavrakou, T., Dils, B., De Smedt, I., Hermans, C., Merlaud, A., Scolas, F., Senten, C., Vanhaelewyn, G., Fally, S., Carleer, M., Metzger, J.-M., Müller, J.F., Van Roozendael, M., and De Mazière, M.: Ground-based FTIR and MAX-DOAS observations of formaldehyde at Réunion Island and comparisons with satellite and model data, Atmos. Chem. Phys., 9, 9523-9544, doi:10.5194/acp-9-9523-2009, 2009.

Wagner, T., Beirle, S., Brauers, T., Deutschmann, T., Frieß, U., Hak, C., Halla, J. D., Heue, K. P., Junkermann, W., Li, X., Platt, U., and Pundt-Gruber, I.: Inversion of tropospheric profiles of aerosol extinction and $\mathrm{HCHO}$ and $\mathrm{NO}_{2}$ mixing ratios from MAX-DOAS observations in Milano during the summer of 2003 and comparison with independent data sets, Atmos. Meas. Tech., 4, 2685-2715, doi:10.5194/amt-4-2685-2011, 2011.

Weibull, W.: A statistical distribution function of wide applicability, J. Appl. Mech.-T. ASME, 18, 293-297, 1951.

Wert, B. P., Trainer, M., Fried, A., Ryerson, T. B., Henry, B., Potter, W., Angevine, W. M., Atlas, E., Donnelly, S. G., Fehsenfeld, F. C., Frost, G. J., Goldan, P. D., Hansel, A., Holloway, J. S., Hubler, G., Kuster, W. C., Nicks Jr., D. K., Neuman, J. A., Parrish, D. D., Schauffler, S., Stutz, J., Sueper, D. T., Wiedinmyer, C., and Wisthaler, A.: Signatures of terminal alkene oxidation in airborne formaldehyde measurements during TexAQS 2000, J. Geophys. Res., 108, 4104, doi:10.1029/2002JD002502, 2003.

Wittrock, F., Richter, A., Oetjen, H., Burrows, J. P., Kanakidou, M., Myriokefalitakis, S., Volkamer, R., Beirle, S., Platt, U., and Wagner, T.: Simultaneous global observations of glyoxal and 
formaldehyde from space, Geophys. Res. Lett., 33, L16804, doi:10.1029/2006GL026310, 2006.

Xiao, Y., Logan, J. A., Jacob, D. J., Hudman, R. C., Yantosca, R., and Blake, D. R.: Global budget of ethane and regional constraints on U. S. sources, J. Geophys. Res., 113, D21306, doi:10.1029/2007JD009415, 2008.

Zander, R., Mahieu, E., Demoulin, P., Duchatelet, P., Roland, G., Servais, C., Mazière, M. D., Reimann, S., and Rinsland, C. P.: Our changing atmosphere: evidence based on long-term infrared solar observations at the Jungfraujoch since 1950, Sci. Total Environ., 391, 184-195, doi:10.1016/j.scitotenv.2007.10.018, 2008.
Zander, R., Duchatelet, P., Mahieu, E., Demoulin, P., Roland, G., Servais, C., Auwera, J. V., Perrin, A., Rinsland, C. P., and Crutzen, P. J.: Formic acid above the Jungfraujoch during 1985-2007: observed variability, seasonality, but no long-term background evolution, Atmos. Chem. Phys., 10, 10047-10065, doi:10.5194/acp-10-10047-2010, 2010. 